\title{
Impacts of physical data assimilation on the Global Ocean Carbonate System
}

\author{
L. Visinelli ${ }^{1}$, S. Masina ${ }^{1,2}$, M. Vichi ${ }^{1,2}$, and A. Storto ${ }^{1}$ \\ ${ }^{1}$ CMCC Centro Euro-Mediterraneo per i Cambiamenti Climatici, Bologna, Italy \\ ${ }^{2}$ INGV Istituto Nazionale di Geofisica e Vulcanologia, Bologna, Italy
}

Received: 17 February 2014 - Accepted: 19 March 2014 - Published: 4 April 2014

Correspondence to: L. Visinelli (luca.visinelli@cmcc.it)

Published by Copernicus Publications on behalf of the European Geosciences Union.

Impacts of physical data assimilation on

the Global Ocean

Carbonate System

L. Visinelli et al.

\section{Title Page}

Abstract Introduction

Conclusions References

Tables Figures

14 $\rightarrow$

4

Back

Close

Full Screen / Esc

Printer-friendly Version

Interactive Discussion 


\section{Abstract}

Prognostic simulations of ocean carbon distribution are largely dependent on an adequate representation of physical dynamics. In this work we show that the assimilation of temperature and salinity in a coupled ocean-biogeochemical model significantly im5 proves the reconstruction of the carbonate system variables over the last two decades. For this purpose, we use the NEMO ocean global circulation model, coupled to the Biogeochemical Flux Model (BFM) in the global PELAGOS configuration. The assimilation of temperature and salinity is included into the coupled ocean-biogeochemical model by using a variational assimilation method. The use of ocean physics data assimilation

run run as assessed by comparing with independent time series and gridded datasets. At the global scale, the effects of the assimilation of physical variables in the simulation of $p \mathrm{CO}_{2}$ improves the seasonal cycle in all basins, getting closer to the SOCAT estimates. Biases in the partial pressure of $\mathrm{CO}_{2}$ with respect to data that are evident in the control run are reduced once the physical data assimilation is used. The root mean squared errors in the $p \mathrm{CO}_{2}$ are reduced by up to $30 \%$ depending on the ocean basin considered. In addition, we quantify the relative contribution of biological carbon uptake on surface $p \mathrm{CO}_{2}$ by performing another simulation in which biology is neglected in the assimilated run.

\section{Introduction}

Carbon dioxide has steadily increased in the atmosphere since the mid-nineteenth century, with a mean global atmospheric concentration estimated in $395.2 \mathrm{ppm}$ as of August 2013 (Conway and Tans, 2013). This increase, which has resulted in more than a $30 \%$ growth in $\mathrm{CO}_{2}$ from the pre-industrialized era to present time, has been mainly imputed to the changes in human activities. Both land and the ocean act as sinks capable of absorbing fractions of atmospheric $\mathrm{CO}_{2}$ (Le Quéré et al., 2013). For example,
Impacts of physical data assimilation on the Global Ocean Carbonate System

L. Visinelli et al.

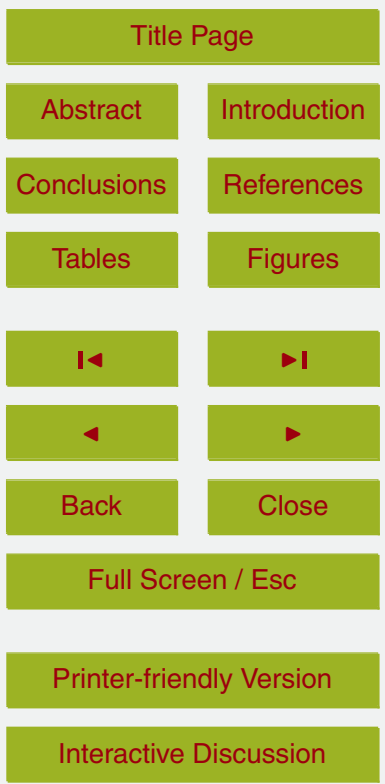


in 2012 the rate of global carbon emission from combustion was $9.7 \pm 0.5 \mathrm{PgCyr}^{-1}$ and about one fourth can be putatively absorbed by the ocean (Sarmiento et al., 2010) with a currently estimated rate of $2.9 \pm 0.5 \mathrm{PgCyr}^{-1}$ (Le Quéré et al., 2013). Assessing the oceanic storage of carbon is key to the closure of the global carbon budget 5 as one of the most uncertain terms like the residual terrestrial sink is usually derived by difference from atmospheric growth rate and ocean uptake (Canadell et al., 2007; Le Quéré et al., 2012). There is concern that in the future the capability of the ocean to absorb atmospheric $\mathrm{CO}_{2}$ from the atmosphere would diminish because of climate change (Sarmiento and Le Quéré, 1996; Matear and Hirst, 1999; Joos et al., 1999; Le Quéré et al., 2007, 2010; Ballantyne et al., 2012), therefore posing an even larger focus on the adequate estimation of current ocean-atmosphere fluxes. Gruber et al. (2009) provided an overview of the different methodologies to assess this flux that span from inverse modeling techniques (Gloor et al., 2003; Mikaloff Fletcher et al., 2007) to prognostic physical-biogeochemical OGCM (Watson and Orr, 2003; Matsumoto et al., land, 2007).

The capability of the ocean to act as a sink for carbon dioxide is determined by the surface partial pressure of $\mathrm{CO}_{2}\left(\mathrm{CCO}_{2}\right)$, which is in turn regulated by the atmospheric concentration, chemical solubility, transport processes, and biological activities.

20 All of these dynamical and biogeochemical terms are included in global Earth System models (Crueger et al., 2008; Le Quéré et al., 2010; Vichi et al., 2011) with respectively growing degrees of uncertainties. Chemical equilibrium of $\mathrm{CO}_{2}$ in the ocean is described by reaction constants that are well-defined in laboratory experiments and controlled by temperature, salinity and pressure conditions (Zeebe and Wolf-Gladrow, jor uncertainties are mostly related to coarse spatial resolutions and sub grid scale parameterizations. Different realizations of ocean dynamics have been demonstrated to drive substantial differences in the resulting fields of carbon system variables even when using a rather simplified biogeochemical model (Doney et al., 2004). The large

Impacts of physical data assimilation on the Global Ocean Carbonate System

L. Visinelli et al.

Title Page

Abstract Introduction

Conclusions

Tables

References

Figures

14

4

Back

Full Screen / Esc

Printer-friendly Version

Interactive Discussion $\rightarrow$

Close 
number of biogeochemical models used in coupled OGCMs (Matsumoto et al., 2004) is an indication that there are few evidence-based constraints on biological processes, whose knowledge is derived heuristically from laboratory experiments and in situ measurements from the world ocean at necessarily limited spatial and temporal resolutions.

5 Even if uncertain, the biogeochemical component is essential to the description of the system and it has to be included. At the same time, it is reasonable to assume that further reducing the uncertainties on the ocean physics may already bring considerable improvements. Additional sources of uncertainty are given by the parametrization of the $\mathrm{CO}_{2}$ flux that is usually based on empirical estimates of the exchange at the 10 interface, see Wanninkhof (1992). The reconstruction of the space and time evolution of surface $p \mathrm{CO}_{2}$ is thus the first step towards constraining ocean-atmosphere carbon fluxes. In order to achieve this the major carbonate system variables such as dissolved inorganic carbon (DIC), total alkalinity, or pH (see an overview in Sect. 2.4) have to be prognostically simulated. Only recently, the scientific literature reported on the assimi15 lation of these carbonate variables or of the carbonate partial pressure into a coupled OGCM with a biogeochemical model, to help improving the reanalysis of the $p \mathrm{CO}_{2}$. Ridgwell et al. (2007) used an ensemble Kalman filter method to assimilate alkalinity and phosphates into the global Grid ENabled Integrated Earth oceanic model, coupled to a model to resolve biogeochemistry. Valsala and Maksyutov (2010) modeled the ocean carbon cycle by coupling a biogeochemical model to an offline transport model for physical circulation, assimilating $p \mathrm{CO}_{2}$ data with a variational method. However, the authors do not focus on the benefits of the assimilation of physical data, which are present in both their runs. While et al. (2012) modified the FOAM data assimilation system to include global $p \mathrm{CO}_{2}$ data into the reanalysis for temperature and salinity, using the NEMO ocean model coupled to the HadOCC biogeochemical model. However, because at present there still is a lack of a global network for collecting $p \mathrm{CO}_{2}$, as opposed to an established and well maintained monitoring observation network for the physical state of the global ocean (see http://www.argo.ucsd.edu), a different approach based on the assimilation of physical quantities is worth exploring. In this work,

Impacts of physical data assimilation on the Global Ocean Carbonate System

L. Visinelli et al.

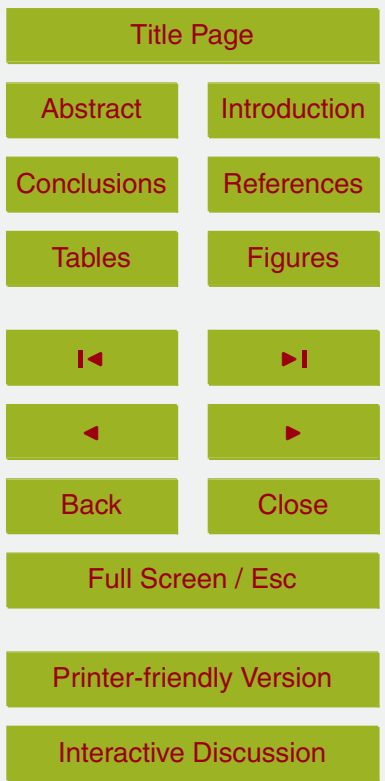


we demonstrate how a reanalysis of the physical components of the ocean by means of physical data assimilation leads to an improved description of the carbonate system variables that is closer to the actual observed data. For this, we used a physical biogeochemical OGCMs coupled online to an ocean data assimilation system (ODA)

5 for assimilating the physical components, and we run two basic simulations, one with OceanVar assimilating physical data and another without. Carbon components or other biogeochemical variables were not assimilated in this phase to highlight the benefits that the model gains from the improved physics only. Independent carbon data from publicly available global ocean databases and gridded fields are used to objectively 10 assess the role of a more realistic ocean physics. To the best of our knowledge, a work on a surface $p \mathrm{CO}_{2}$ reconstruction derived from an ocean physical reanalysis has never been presented before. This paper is organized as follows. Section 2 describes the features of the models used, the ODA system, and the dataset used for the assimilation of temperature and salinity and for the validation of the biogeochemical model. In addition, 15 in Sect. 2.4 we provide a brief introduction to the relationship between the carbonate variables on temperature and salinity. In Sect. 3, we describe the improvements in the reconstruction of the temperature and salinity fields due to the data assimilation method. Section 4 presents the effects of physical data assimilation on the carbonate system variables, while Sect. 5 discusses the impact on $p \mathrm{CO}_{2}$.

\section{Methods}

\subsection{Oceanic Global Circulation Model}

The OGCM is the Nucleus for European Modeling of the Ocean (NEMO) version 3.4, in the ORCA2 configuration (Madec and Imbard, 1996), coupled with the LouvainLa-Neuve sea-ice model (Fichefet and Maqueda, 1997). The ORCA2 grid consists of 25 a mesh of horizontal resolution $2^{\circ} \times 2^{\circ} \cos \phi$, except in the $20^{\circ} \mathrm{N}-20^{\circ} \mathrm{S}$ belt where the meridional grid spacing reduces to $0.5^{\circ}$. The grid is irregular and features three poles,
BGD

$11,5399-5441,2014$

Impacts of physical

data assimilation on

the Global Ocean

Carbonate System

L. Visinelli et al.

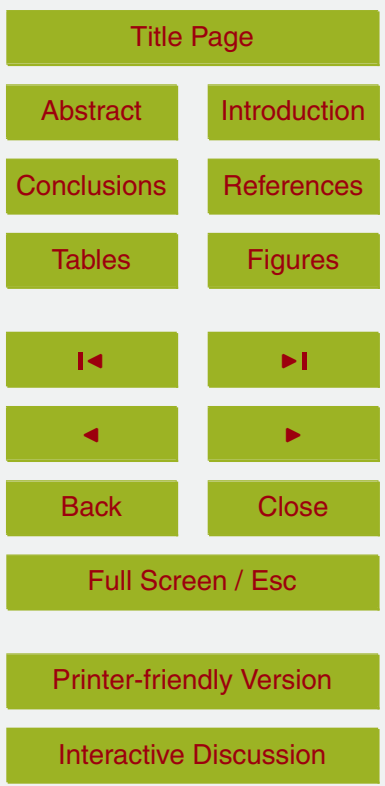


two of which are located over the land regions in the Northern Hemisphere and the third over Antarctica. The number of ocean vertical levels is 30,20 of which are located in the top $500 \mathrm{~m}$. In the model, the oceanic surface is forced through the CORE bulk formulation (Large and Yeager, 2008), using atmospheric fields from the European Centre 5 for Medium-Range Weather Forecasts (ECMWF) ERA-INTERIM reanalysis (Dee et al., 2011). The reanalysis data consist of 3 hourly forcing for wind velocity components, air temperature and humidity at $2 \mathrm{~m}$, together with the daily rates of snowfall, total precipitation, and incoming shortwave and longwave radiations. The river runoff input is a monthly climatology derived from the Dai and Trenberth (2002) dataset. The net 10 freshwater flux is corrected by means of the relaxation towards the World Ocean Atlas 2009 (http://www.nodc.noaa.gov/) monthly climatology of sea surface salinity, with a relaxation timescale corresponding to 300 days for a 50 m deep mixed layer. An additional three-dimensional relaxation is applied northward of $60^{\circ} \mathrm{N}$ and southward of $60^{\circ} \mathrm{S}$ in order to avoid high-latitude model drifts. A laplacian operator is used for the diffusion of tracers and momentum. The advection of tracers is achieved with the MUSCL scheme (Monotone Upstream-centered Schemes for Conservation Laws), while the Turbulent Eddy Kinetic (TKE) dependent vertical diffusion scheme (Blanke and Delecluse, 1993) is used to compute the vertical mixing coefficient.

Initial conditions for the temperature and salinity fields are derived from the Locarnini et al. (2010) data set, whereas the zonal and the meridional components of the velocity fields start from rest. Throughout this paper, we will always refer to the "control" run (CTRL) as the simulation obtained by the PELAGOS model without assimilating the observed data, while we refer to the "assimilation" run (TSREAN) as the reanalysis result of the assimilation of temperature and salinity data in the PELAGOS-OceanVar model (see Table 1). Both implementations use exactly the same parameterizations for the oceanic and the biogeochemical models. Both CTRL and TSREAN start from the rest ocean on 1 January 1988, ending on 31 December 2010.
BGD

$11,5399-5441,2014$

Impacts of physical data assimilation on the Global Ocean Carbonate System

L. Visinelli et al.

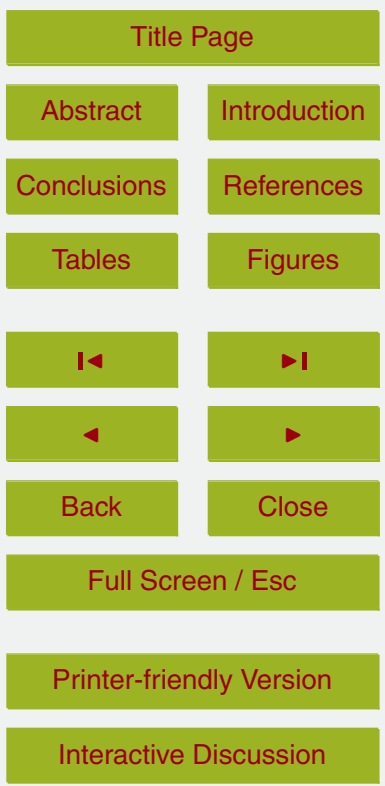




\subsection{Biogeochemical model}

The Biogeochemical Flux Model (BFM, Vichi et al., 2007a, b) describes the dynamics of major biogeochemical processes occurring in the marine systems. The model is based on a set of differential equations describing the interactions between the fluxes of

5 various nutrients and specific biological functional groups. The BFM describes a continuum biomass representation of the lower trophic levels of the marine ecosystem. The model implements a set of biomass-based differential equations that solve the fluxes of nutrients (carbon, nitrogen, phosphorus, silicate and iron) among selected biological functional groups (phytoplankton, zooplankton and bacteria) representing the major components of the lower trophic levels. A scheme of the state variables and resolved physiological and ecological processes is available on the model web page (http://bfm-community.eu) where it is also possible to download the code and access the full documentation. Although the model is capable of describing 52 pelagic state variables with relative diagnostics, for the purpose of this work we will mainly focus on the simulation of the carbonate system variables that are further described in Sect. 2.4. The BFM is coupled to the global NEMO 3.4 hydrodynamics model in the so-called PELAGOS configuration (Vichi and Masina, 2009). The adjustment period of the surface biogeochemical component of PELAGOS is about five years, as we have tested by observing the time required for the $\mathrm{CO} 2$ flux to reach a repeating cycle with perpetual year forcings. For this reason, the statistics in the carbonate variables are computed by considering the run over the period January 1993-December 2010, thus removing the first 5 years of adjustment to the variability of the inter-annual forcing.

Initial conditions for DIC are derived from the GLODAP annual climatologies (Key et al., 2004), interpolated on the ORCA2 grid. For the alkalinity, we have modified the original GLODAP dataset by lowering the value of the alkalinity in the Pacific basin by $50 \mu \mathrm{mol} \mathrm{kg}^{-1}$ over the whole water column. This choice for the alkalinity was necessary because the value of the alkalinity at the Hawaii Ocean Time Series (HOT, see Sect. 2.5) is lower than the climatological GLODAP in the 1980's by around

Impacts of physical data assimilation on the Global Ocean Carbonate System

L. Visinelli et al.

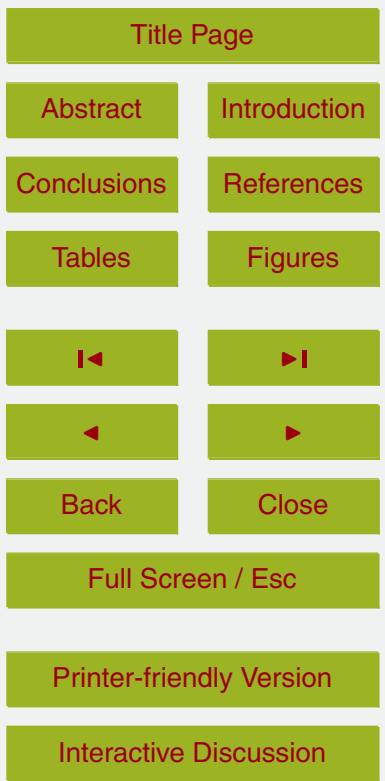


$50 \mu \mathrm{molkg}{ }^{-1}$, a quantity that cannot be removed by physical and chemical processes which are alkalinity-conserving. The carbonate flux at the ocean surface is forced by using the atmospheric $p \mathrm{CO}_{2}$ provided in the CMIP5 climate model intercomparison (http://cmip-pcmdi.Ilnl.gov/cmip5/).

5 In the model, the net flux of $\mathrm{CO}_{2}$ is proportional to the difference between the partial pressure of $\mathrm{CO}_{2}$ at the sea surface and in the atmosphere, using the parametrization of Wanninkhof (1992).

\subsection{Ocean Data Assimilation scheme}

In order to better reconstruct the physical ocean fields, the PELAGOS model has been 10 coupled with the global implementation (Storto et al., 2011) of a three-dimensional variational ODA scheme, here OceanVar (Dobricic and Pinardi, 2008). The frequency of the data assimilation step is of 10 days. In the OceanVar scheme, the background error covariance of the model state is separated into a sequence of operators, accounting for the statistical estimation of the horizontal and vertical error covariances of temperature 15 and salinity. Thanks to the structure of the background error covariance matrix, corrections are spread over both temperature and salinity by bivariate Empirical Orthogonal Functions (EOFs). This implies that, when only one of the two physical quantities is assimilated, vertical corrections apply to the other as well.

The bivariate EOFs have been estimated by the dataset of monthly anomalies with respect to the monthly climatology from an assimilation-free simulation. In order to model horizontal correlations, a 4-iteration first-order recursive filter is used, with a uniform horizontal correlation length-scale equal to $300 \mathrm{~km}$. The OceanVar system also takes advantage of an extended domain with duplicated observations on the symmetric extension zones, which serves the purpose of obtaining cyclic conditions during the application of the recursive filter.

Observational errors are derived from the Ingleby and Huddleston (2007) profiles of instrumental errors, which are subsequently inflated to account for large representa-

Impacts of physical data assimilation on the Global Ocean Carbonate System

L. Visinelli et al.

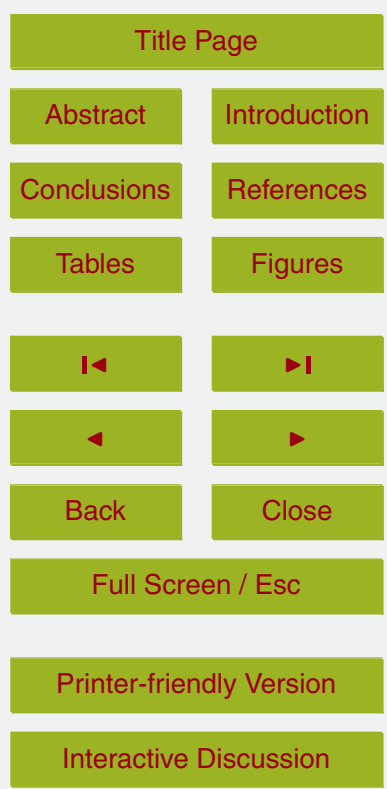


tiveness errors in correspondence of areas of strong variability. The OceanVar system also performs several data quality check, among which a check against the climatology and a check against background fields that rejects observations with a too large departure from the model fields.

\section{$5 \quad 2.4$ Carbonate system variables}

In the PELAGOS model, the set of carbonate system variables are evaluated at each step by numerically computing the coupled advection-diffusion-reaction equation. Carbon equilibrium and dissociation constants are computed according to the OCMIP2 protocol and reaction constants described in Zeebe and Wolf-Gladrow (2001), with the 10 reaction coefficients in Mehrbach et al. (1973). In this work, we revise whether the assimilation of physical data is beneficial to the estimate of the carbonate system variables, because of improvements in the transport field and because of direct effects of temperature and salinity on the three main components of the carbonate system: the dissolved inorganic carbon (DIC), the alkalinity (ALK), and the partial pressure of gaseous $\mathrm{CO}_{2}$ in water $\left(p \mathrm{CO}_{2}\right)$.

Dissolved inorganic carbon in the ocean is the sum of three inorganic carbon forms: effective carbonic acid $\mathrm{H}_{2} \mathrm{CO}_{3}^{*}$, bicarbonate ion $\mathrm{HCO}_{3}^{-}$, and carbonate ion $\mathrm{CO}_{3}^{2-}$,

$\mathrm{DIC}=\left[\mathrm{H}_{2} \mathrm{CO}_{3}^{*}\right]+\left[\mathrm{HCO}_{3}^{-}\right]+\left[\mathrm{CO}_{3}^{2-}\right]$.

20 Alkalinity is formally defined as the equivalent sum of the bases that are titratable with strong acids. In practice, alkalinity measures the capacity of water to neutralize an acid, and it is obtained by keeping track of the charge balance in the sea by defining

$\mathrm{ALK}=\left[\mathrm{HCO}_{3}^{-}\right]+2\left[\mathrm{CO}_{3}^{2-}\right]+\left[\mathrm{B}(\mathrm{OH})_{4}^{-}\right]+\left[\mathrm{OH}^{-}\right]-\left[\mathrm{H}^{+}\right]+$(minor anions)

25 Here, $\left[\mathrm{B}(\mathrm{OH})_{4}^{-}\right]$indicates the concentration of the borate ion. Alkalinity is conserved during changes in temperature and pressure, and it is closely related to changes in 5407
BGD

$11,5399-5441,2014$

Impacts of physical data assimilation on

the Global Ocean

Carbonate System

L. Visinelli et al.

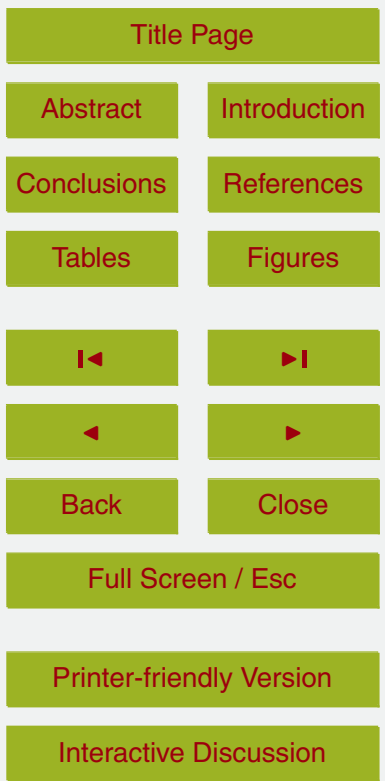


salinity. Since variations in the salinity are due to precipitation, evaporation, fresh water inflow, and formation or melting of sea ice, corresponding changes in the alkalinity are lead by the same processes.

The partial pressure of the gaseous $\mathrm{CO}_{2}$ is proportional to the concentration of $5 \mathrm{H}_{2} \mathrm{CO}_{3}^{*}$ as

$$
\left[\mathrm{H}_{2} \mathrm{CO}_{3}^{*}\right]=K_{0} p \mathrm{CO}_{2} \text {, }
$$

where $K_{0}$ is a temperature-depending constant describing the solubility of $p \mathrm{CO}_{2}$ (see Weiss, 1974). Thus, $p \mathrm{CO}_{2}$ is a function of $T$ and $S$, besides DIC, and ALK. We can appreciate the changes in $p \mathrm{CO}_{2}$ in a closed system driven by temperature and salinity, by using the empirical sensitivities in (Takahashi et al., 1993):

$$
\frac{\partial \ln p \mathrm{CO}_{2}}{\partial T} \approx \theta, \text { and } \frac{\partial \ln p \mathrm{CO}_{2}}{\partial \ln S} \approx 1 \text {, }
$$

where $\theta=0.0423^{\circ} \mathrm{C}^{-1}$. Since we obtain that typical differences in the temperature 15 ar

$\Delta S=0.05$ (see Table 5 below), we expect from the expressions above that $p \mathrm{CO}_{2}$ be corrected by

$$
\frac{\Delta p \mathrm{CO}_{2}}{p \mathrm{CO}_{2}} \approx \theta \Delta T \approx 1 \%, \text { and } \frac{\Delta p \mathrm{CO}_{2}}{p \mathrm{CO}_{2}} \approx \frac{\Delta S}{S} \approx 0.15 \% \text {. }
$$

20 As it will be shown in Sect. 3, the assimilation of temperature and salinity may change $p \mathrm{CO}_{2}$ by $0-30 \%$, depending on the ocean basin considered (see Table 5 below), because of indirect changes induced by the improvements in the transport terms.

\subsection{Datasets}

In this work, temperature and salinity datasets are used for the assimilation and for the verification of the assimilative run TSREAN. Climatological reanalyses of sea surface temperature and salinity and carbonate dataset are used for the validation of the physical and biogeochemical component of the TSREAN model.
$11,5399-5441,2014$

Impacts of physical data assimilation on

the Global Ocean

Carbonate System

L. Visinelli et al.

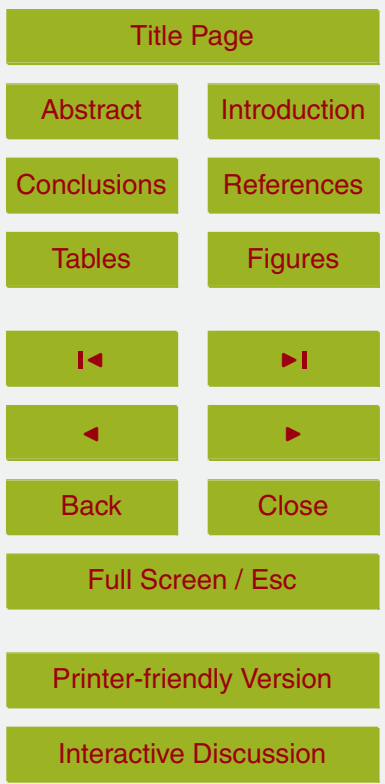


Global data for temperature and salinity fields used for the assimilation are taken from the EN3 (ENACT Quality Checked) dataset (Ingleby and Huddleston, 2007). Each measurement has been quality controlled by using a set of objective tests, with data available from 1950 to present day. This collection comprises several independent data 5 sources from various instrumentation like moored (MBT) and expendable bathythermographs (XBT), conductivity-temperature-depth (CTD) profiles, moored buoys, and floats like the instrumentations used in the ARGO project. More specifically, the moored buoys considered are the PIRATA floats in the Atlantic basin, the TOGA-TAO floats in the Pacific basin, and the RAMA floats in the Indian ocean (McPhaden et al., 1998).

10 For validating the model, we considered the sea surface temperature (SST) climatology developed by Reynolds et al. (2007) from the National Climatic Data Center (NCDC) and the Climate Prediction Center (CPC/NOAA), and the sea surface salinity (SSS) climatology provided by Locarnini et al. (2010), which comprises monthly climatological salinity maps using data from 1950 to 2008.

15 Additional local verifications on the physical variables are given by comparing results with the time series collected at two different stations, the Bermuda Atlantic Time Series (BATS) and the Hawaii Ocean Time series (HOT). At both stations, CTD data are taken starting 1 October 1988, with profiles ranging over 0-4300 m depth at BATS, and over 0-5000 m depth at HOT. We have assessed the Mixed Layer Depth (MLD) at BATS and HOT station, against data from the Joint Global Ocean Flux Study (JGOFS) for the years 1989-2000. In addition, complete independent time series for the carbonate system components (DIC and alkalinity) are available at BATS and HOT, with the same profiles and time ranges as for temperature and salinity. Over the 23 years considered, the number of data for the DIC and the ALK in BATS are only $N_{\text {DIC }} \sim 3600$ and $N_{\text {ALK }} \sim$ 2500 , clustered over specific days when detectors are deployed, while the number of both DIC and alkalinity data at HOT is $N_{\mathrm{DIC}} \sim N_{\mathrm{ALK}} \sim 4500$. In order to asses the surface $p \mathrm{CO}_{2}$, we used the Surface Ocean $\mathrm{CO}_{2}$ Atlas (SOCAT) gridded dataset of direct global $p \mathrm{CO}_{2}$ measurements (Sabine et al., 2013), which reports measurements of $p \mathrm{CO}_{2}$ at surface water, obtained from 1968 to 2007.
BGD

$11,5399-5441,2014$

Impacts of physical

data assimilation on

the Global Ocean

Carbonate System

L. Visinelli et al.

Title Page

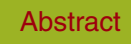

Introduction

Conclusions

Tables

References

Figures

14

4

Back

Full Screen / Esc

Printer-friendly Version

Interactive Discussion 


\section{Assessment of temperature and salinity}

To assess the overall quality of the OceanVar assimilation scheme, we computed the bias of the global SSS and SST obtained from the two runs, CTRL and TSREAN, with respect to the climatological reanalyses introduced in Sect. 2.5 (Fig. 1). In the CTRL, 5 the largest negative salinity deviations from the Levitus climatology are found in the equatorial Atlantic and in the Indonesian ocean, while the largest positive deviations lie in the northern Pacific and the Antarctic Circumpolar Current (ACC) region (Fig. 1a, b).

For the SST, the CTRL run shows a significant bias with values below $-0.5^{\circ} \mathrm{C}$ in the northern Pacific, the northwest Atlantic, and southern Australia, and a bias larger than $0.5^{\circ} \mathrm{C}$ at tropical latitudes and near most of the coasts (Fig. 1c). The assimilation of temperature data has reduced both these overall biases, with values above $0.5^{\circ} \mathrm{C}$ only in smaller regions of the western boundary currents, in the south eastern Atlantic, and in the patchy spots south of $60^{\circ} \mathrm{S}$ (Fig. 1d). The large bias in the Gulf stream has not been reduced by the assimilation because of the coarse resolution used. In conclusion, the assimilation of temperature and salinity globally reduces the surface temperature and salinity biases with respect to the climatology.

In order to test the efficiency of the assimilation process, we compute the root mean squared error (RMSE) between data and model as follows. Assume we are given a set of in situ observations for the variable $\alpha,\left\{x_{i}^{\alpha}\right\}$, where $i \in\{1, \ldots, N\}$ and where $N$ is the number of samplings in both time and space for $\alpha$. The RMSE is defined as

$\operatorname{RMSE}_{M}^{\alpha}=\sqrt{\sum_{i=1}^{N} \frac{\left(M_{i}^{\alpha}-x_{i}^{\alpha}\right)^{2}}{N}}$

where $M_{i}^{\alpha}$ is obtained by the model run (either control or assimilation) by a linear interpolation in depth and time coordinates to fit the data point $x_{i}^{\alpha}$. In horizontal dimensions, we do not interpolate over the station latitude and longitude, but we consider the ORCA2 grid point that is closest to each station. The difference $M_{i}^{\alpha}-x_{i}^{\alpha}$ is called misfit.

Impacts of physical data assimilation on the Global Ocean Carbonate System

L. Visinelli et al.

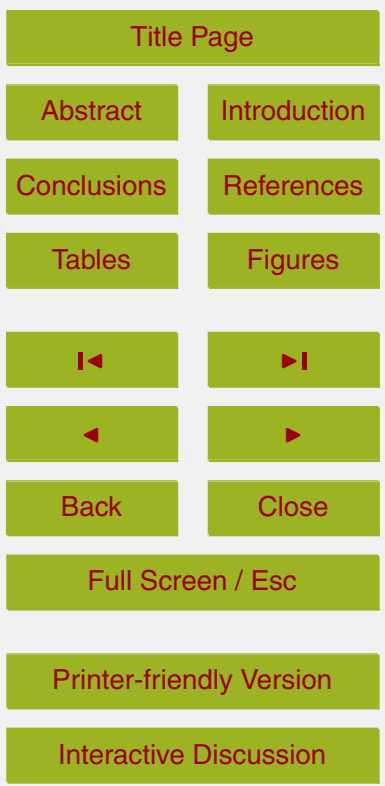


In Fig. 2, we compare the root-mean square value for the misfits of salinity (Fig. 2a) and temperature (Fig. 2b), for both CTRL and TSREAN. The statistics for the global ocean have been computed by using the complete set of in situ data used in the reanalysis from different types of instruments, while all the other statistics presented in 5 specific ocean basins are computed using data from mooring buoys only. Salinity is corrected by about $25 \%$ at the global scale, by $30 \%$ in the Atlantic and Pacific oceans, and by $40 \%$ in the Indian ocean. Both at the global scale and over the three basins, the temperature RMSE of the assimilation run falls at around $\Delta T \sim 0.8^{\circ} \mathrm{C}$, with an average reduction of about $25 \%$ for the global ocean and $35 \%$ in the three basins, with respect to the control run.

At HOT and BATS stations, the temperature RMSE for the control run respectively results $1.0^{\circ} \mathrm{C}$ and $1.8^{\circ} \mathrm{C}$, while assimilation reduces both RMSE to be $0.8^{\circ} \mathrm{C}$ and $0.6^{\circ} \mathrm{C}$, thus correcting temperature by about $20 \%$ at HOT and $65 \%$ at BATS. Similarly, salinity is corrected by $30 \%$ at HOT and by $70 \%$ at BATS. This different behavior between HOT and BATS has been further investigated by the comparison of time series at these two locations.

In Table 2, we report the mean and standard deviation for the time series of TSREAN and CTRL temperature and salinity at HOT and BATS stations. We have performed this analysis considering either the surface ocean within the first ten meters depth which corresponds to the first vertical level for the ORCA2 grid, or the whole water columns that have been shown in Fig. 2. In addition, we have computed the RMSE and the correlation of these time series with data collected at the two locations. The RMSE has been reduced in TSREAN for all quantities, at both stations, and both at surface and over the entire vertical profile, because of the direct assimilation of such quantities in the ocean reanalysis. In particular, the SST improves by about $5 \%$ at HOT and by $9 \%$ at BATS, while SSS improves by $54 \%$ at HOT and by $29 \%$ at BATS. At both locations, the mean value for the SSS for the TSREAN differs by more than one standard deviation with respect to the mean SSS for CTRL, and lies closer to the mean of the observed data. Finally, the Pearson correlation $r$ computed between TSREAN

Impacts of physical data assimilation on the Global Ocean Carbonate System

L. Visinelli et al.

Title Page

Abstract Introduction

Conclusions

Tables

References

Figures

14

4

Back

Full Screen / Esc

Printer-friendly Version

Interactive Discussion 
and CTRL with respect to data is higher than 0.9 for temperature and for salinity over the whole water column at BATS.

In Fig. 3, we have compared the time series of TSREAN and CTRL surface temperature and salinity with data collected at HOT and BATS stations. As we inferred from 5 the statistics, the SSS is significantly improved by the data assimilation at HOT station, with respect to the CTRL run, which simulates values that are off by up to 0.5 over that region, and shows a much less pronounced inter-annual variability with respect to the observations. At BATS station, the assimilation of salinity corrects both the average value and the amplitude of the oscillation of the salinity cycle with respect to the con10 trol run. Also, sea surface temperature at both BATS and HOT is improved, since the correction provides a better reconstruction of the inter-annual peaks.

We have also compared the value of the model MLD with the time series reported from the JGOFS stations at HOT and BATS. Here, we have defined the MLD as the depth at which temperature varies by more than $0.2^{\circ} \mathrm{C}$ with respect to the surface tem15 perature. Results are shown in Fig. 4. At HOT, the MLD from the TSREAN does not show a significant improvement towards data with respect to CTRL, as can be quantitatively concluded from the RMSE and the correlation reported in Table 3, which do not change significantly between the two runs. At BATS, the inter-annual variability and the depths of the MLD peaks are closer to observed data in TSREAN than in CTRL. Consistently with observations, stratification occurs earlier in the year in TSREAN than in CTRL. In facts, the correlation reported in Table 3 between JGOFS data and TSREAN is $r=0.87$, while we obtained $r=0.78$ between JGOFS data and CTRL. These results improve with respect to the assessment of an older version of the PELAGOS model against BATS JGOFS data presented in (Vichi and Masina, 2009), where the value

$25 r=0.81$ is reported. This improvement can be partially resulting from the different time scale used for the comparison, since for each quantity in the run we saved a five-days average while in (Vichi and Masina, 2009) a monthly average is used.

Impacts of physical data assimilation on the Global Ocean Carbonate System

L. Visinelli et al.

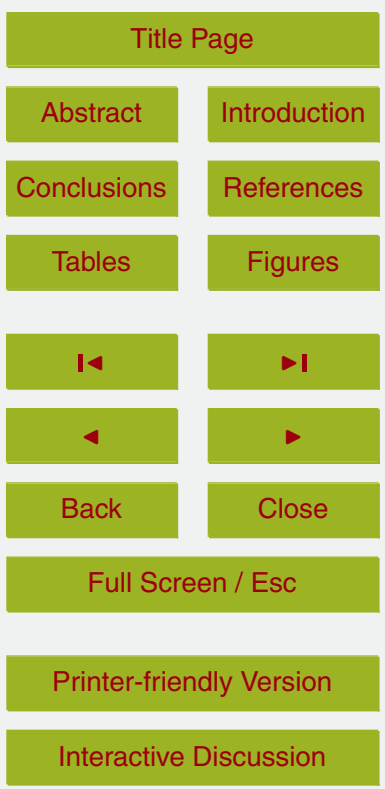




\section{Assessment of DIC and ALK at BATS and HOT stations}

We now discuss how the reconstruction of the carbonate species has improved in TSREAN with respect to the results in CTRL, by computing the RMSE in DIC and ALK at BATS and HOT using Eq. (6) over the whole column data in Fig. 5. We remind 5 here that DIC and ALK are completely independent data since no biogeochemical data have been assimilated. For both variables, the RMSE at BATS largely benefits from the assimilation of the physical variables, with the error being reduced by $75 \%$ for ALK and by $49 \%$ for DIC. In HOT, the relative improvement of the RMSE in the assimilation run is not as large, since ALK improves by $5 \%$ and DIC improves by $13 \%$; however the 10 misfits for ALK for the CTRL in HOT are lower compared to those in BATS by around $64 \%$, meaning that the CTRL is already closer to the actual data in HOT. In Fig. 6 , we show the RMSE as a function of vertical depth. TSREAN improves the results over the first $400 \mathrm{~m}$ depth, while at lower depth they are comparable, except for DIC in HOT where TSREAN worsen. However, since most of the data are collected within the first $400 \mathrm{~m}$ ( $92 \%$ of data in BATS and $63 \%$ in HOT) the assessment is less reliable at deeper depths.

We have underlined these results by showing, in Fig. 7, the time series of the two carbonate species, averaged over the first ten meters depth. Although data do show an increase in the DIC at the surface in both HOT and BATS stations because of atmospheric growth, the CTRL run shows a positive trend which is too steep with respect to data, and with an oscillation amplitude which is smaller than observed, while the assimilation of temperature and salinity in TSREAN reduces the trend and increases the variability in closer agreement with the observations. The ALK in HOT shows an increasing trend after 2005, which is visible also in the observations but starting from a smaller value. As a consequence, significative mismatch with the observations in the last part of the study period is responsible for the worst performance of the surface ALK in TSREAN with respect to the CTRL (Fig. 5b). To better quantify the improvement over both the first level and the whole water column of the simulation of carbonates,
Impacts of physical data assimilation on the Global Ocean Carbonate System

L. Visinelli et al.

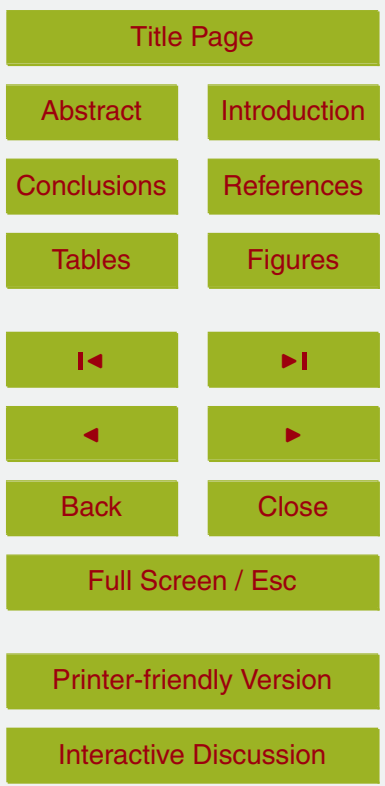


we have computed the mean and standard deviation of the times series in TSREAN, CTRL, and for the datasets in Table 4, together with the RMSE and the Pearson correlation of TSREAN and CTRL with respect to data. As discussed previously, the RMSE over the whole water column decreases because of the assimilation of physical quan5 tities, while at surface it is only the ALK at HOT which shows a lower value of RMSE for the CTRL run with respect to TSREAN, as shown in Fig. 6.

For the ALK in HOT, we remind here that the initial condition for the ALK in the Pacific basin has been modified with respect to the original GLODAP dataset, see Sect. 2.2. In fact, the use of the original climatological dataset led to a bias of about $50 \mathrm{\mu mol} \mathrm{kg}^{-1}$, 10 corresponding to values of the ALK that are found in the ' 90 s but not at earlier decades when our runs start. Although this procedure of modifying the initial condition is arbitrary, it shows that the choice of the correct values largely impacts on the outcome of the run, and a climatology may not be the most adequate choice, particularly in the presence of trends. This procedure can be improved by adopting a data assimilation 15 scheme for the carbonate variables, which is the subject for future work. Alkalinity at BATS shows an unrealistic trend in CTRL when compared to data (see Fig. 7), which is completely removed in TSREAN. In fact, there is a considerable negative bias in surface salinity and the mean annual SST in the region is about $0.5^{\circ} \mathrm{C}$ higher in CTRL than in TSREAN, both facts leading to a higher evaporation and to a more stratified water column at BATS for CTRL. This evaporation leads to a continuous increase in surface alkalinity which is not compensated by changes in physical processes, as it occurs for salinity. Indeed, the same trend is not visible for salinity because evaporation increases density and enhances vertical exchange.

In conclusion, coherently with the results from the physics, where a higher improvement occurs at BATS with respect to HOT, carbonate species also receive a higher benefit with respect to the simulation at BATS.
BGD

$11,5399-5441,2014$

Impacts of physical

data assimilation on

the Global Ocean

Carbonate System

L. Visinelli et al.

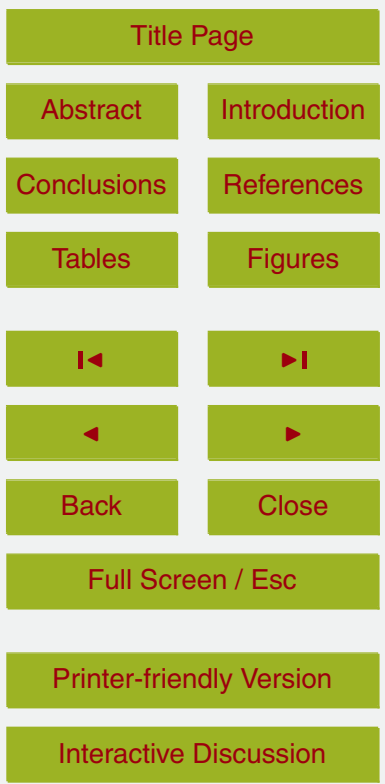




\section{Assessment of the surface $p \mathrm{CO}_{2}$ field}

\subsection{Comparison with the SOCAT global $p \mathrm{CO}_{2}$ dataset}

The quality of TSREAN in terms of the surface $p \mathrm{CO}_{2}$ has been assessed against the Surface Ocean $\mathrm{CO}_{2}$ Atlas (SOCAT, see Sect. 2.5). In Fig. 8a, we show the annual climatological $p \mathrm{CO}_{2}$ field obtained from averaging the monthly climatology provided by this dataset. The Northern Hemisphere is vastly covered, while large regions with no data exist in all southern basins. The gridded SOCAT dataset is compared with the climatological values of $p \mathrm{CO}_{2}$ obtained from CTRL and TSREAN in Fig. 8. The value of $p \mathrm{CO}_{2}$ in CTRL is lower than what reported by SOCAT in the Indian ocean and in the Atlantic ocean south of the equator. The assimilation of physical quantities reduces these biases. Comparing the results in TSREAN with the SOCAT dataset, the $p \mathrm{CO}_{2}$ is still lower in the Pacific Ocean closer to the North American coast, and in the Atlantic Ocean within $30^{\circ} \mathrm{S}$ and $30^{\circ} \mathrm{N}$ latitude, while it remains higher in the North Atlantic Ocean as in the control run. To better show the comparison between the two runs and the dataset, we have added in Fig. 8 the Absolute Average Error (AAE) between the climatological $p \mathrm{CO}_{2}$ for SOCAT and for the simulated climatologies, using the formula

$\mathrm{AAE}=\frac{1}{12} \sum_{i=1}^{12}\left|p \mathrm{CO}_{2}{ }^{m}(i)-p \mathrm{CO}_{2}{ }^{\mathrm{s}}(i)\right|$,

where $s$ stands for SOCAT and $m$ for either CTRL or TSREAN simulations. The TSREAN $p \mathrm{CO}_{2}$ AAE is higher than the CTRL AAE in the Western Equatorial Pacific and in the Eastern Pacific north of $45^{\circ} \mathrm{N}$, but sensibly improves in all other regions, especially in the subtropical gyre regions in both the Atlantic and Pacific Oceans.

The improvements on the overall $p \mathrm{CO}_{2}$ field due to assimilation is quantified in Table 5 , where in the first two columns we have shown the mean value of the $p \mathrm{CO}_{2}$ over various oceanic regions and the standard deviations for CTRL, TSREAN, and the SOCAT dataset. For the two runs, the statistics is computed using only the grid points

Impacts of physical data assimilation on the Global Ocean Carbonate System

L. Visinelli et al.

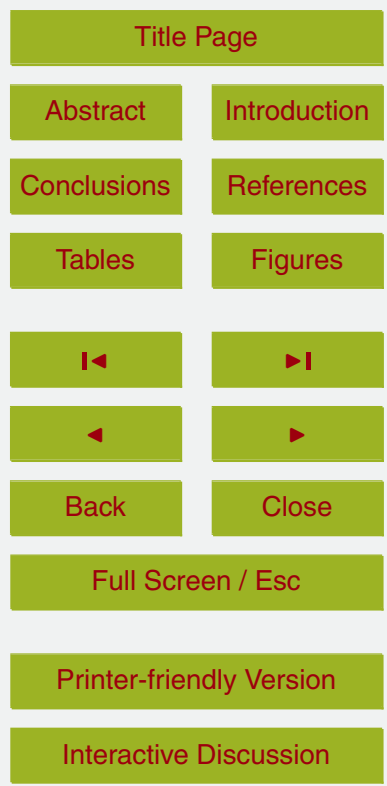


where SOCAT data exist. The mean value of the $p \mathrm{CO}_{2}$ obtained in TSREAN is always larger than the value in CTRL, and closer to the values reported by the SOCAT collaboration, except in the South Atlantic region where the SOCAT dataset is limited to coastal areas. Besides the fact that assimilating physical variables helps reconstruct5 ing the global $p \mathrm{CO}_{2}$, the values found in the tropical and northern Atlantic are still too small compared to the actual data, meaning that our model still fails to reconstruct the carbonate system over these regions.

In the last column of Table 5, we have presented the differences

$$
\Delta \mathrm{RMSE}^{\alpha}=\mathrm{RMSE}_{\mathrm{TSREAN}}^{\alpha}-\mathrm{RMSE}_{\mathrm{CTRL}}^{\alpha}
$$

with $\alpha$ either $p \mathrm{CO}_{2}$, SSS, or SST. For the physical variables, the computation of the RMSE is performed using all of the data used in the assimilation. To compute the RMSE between the SOCAT data and the runs, we have modified Eq. (6) to account for the average over the $1^{\circ} \times 1^{\circ}$ regular SOCAT grid $G_{i}$, as

$15 \operatorname{RMSE}_{M}^{\alpha}=\sqrt{\frac{\sum_{i, t} G_{i}\left(M_{i, t}^{\alpha}-x_{i, t}^{\alpha}\right)^{2}}{\sum_{i, t} G_{i}}}$,

where, once set $\alpha=p \mathrm{CO}_{2}$, we defined $M_{i, t}^{\alpha}$ and $x_{i, t}^{\alpha}$ respectively as the values of the $p \mathrm{CO}_{2}$ at the climatological month $t$ for the model run (either TSREAN or CTRL), and the SOCAT dataset. The summation over $t$ in Eq. (9) runs over the twelve climatological months, while $i$ runs over the grid points at which SOCAT data are present within the given region. In the regions where the RMSE from TSREAN is lower than the RMSE from CTRL, the assimilation of physical variables improves quantitatively the average value of the surface $p \mathrm{CO}_{2}$. This is true for all oceanic regions considered, except for the North Atlantic and South Pacific regions.

Impacts of physical data assimilation on the Global Ocean Carbonate System

L. Visinelli et al.

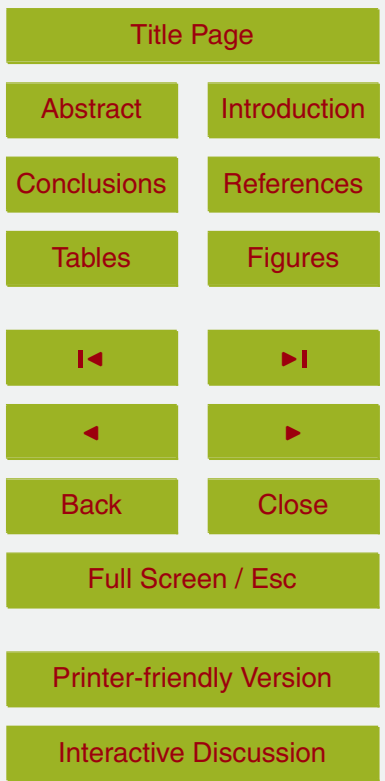




\subsection{Impact of biological processes on the $\mathrm{pCO}_{2}$}

One of the most difficult sources of errors to address in simulating the carbonate system comes from the parametrization of the biological processes. In order to quantify the magnitude of this term, we have performed an additional run in which we assimi-

5 lated temperature and salinity, but we did not include the effects of the biology in the carbonate system dynamics, with the aim to estimate the impact of the biology on the surface $p \mathrm{CO}_{2}$. In the following, we refer to this new run as "TSREAN_NB" (No Biology, see Table 1). TSREAN_NB starts on 1 January 1988 from the same initial conditions as TSREAN, without including any biological process.

In Fig. 9 we have shown the anomaly of the climatological seasonal cycle of $p \mathrm{CO}_{2}$ for the SOCAT data (black line), CTRL (blue line), TSREAN (red line), and TSREAN_NB (green line), averaged over the Atlantic, Pacific, and Indian basins, the first two divided in the northern and southern parts. For the computation of the climatological months, we have used the period 2000-2010, corresponding to the period when the carbonate variables in TSREAN_NB have adjusted from the initial conditions, with no long-term drift deriving from the lack of the biological uptake processes. In the legend, we have reported the average value used for computing the anomalies. For each month $t$, the spatial average is taken only over the SOCAT grid points $i$ at which $p \mathrm{CO}_{2}$ data are present, using the formula

$\left\langle p \mathrm{CO}_{2}(t)\right\rangle=\frac{\sum_{i} G_{i} p \mathrm{CO}_{2}(i, t)}{\sum_{i} G_{i}}$,

where $G_{i}$ is the $1^{\circ} \times 1^{\circ}$ regular SOCAT grid.

Focusing on the CTRL and the TSREAN runs in Fig. 9, we note that the effects of the assimilation of physical variables in the simulation of the $p \mathrm{CO}_{2}$ also improves the seasonal cycle in all basins, getting closer to the SOCAT estimates. When biological processes are not included as in run TSREAN_NB, the seasonal cycle is considerably overestimated during summer and underestimated during winter, especially in the
Impacts of physical data assimilation on the Global Ocean Carbonate System

L. Visinelli et al.

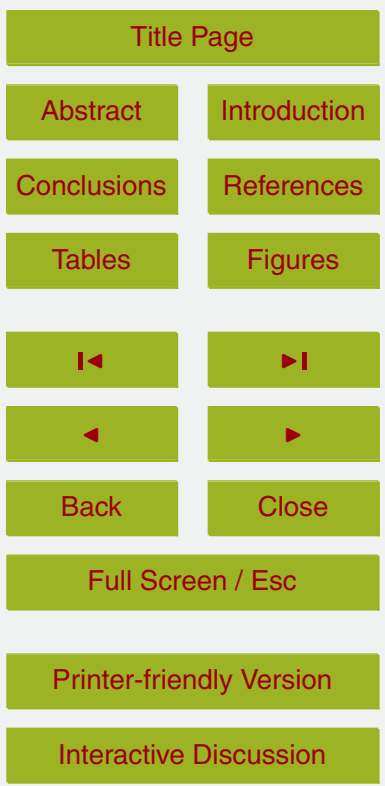


northern parts of the analyzed basins. This mismatch occurs on top of the physical data assimilation correction which indicates how, however uncertain, an active biological parameterization is a necessary term in the dynamical equation. The difference between data and TSREAN_NB may be used as an estimate of the uncertainty in the biological 5 parameterization. Any biogeochemical model that is able to reduce this bias and stay within this range as done by PELAGOS both in the CTRL and TSREAN simulations is to be considered acceptable.

\section{Discussion and conclusions}

Results showed that assimilating temperature and salinity data into the PELAGOS sys10 tem leads to an evident improvement of the performance of the model in the simulation of the carbonate system variables. Our methodology is based on taking advantage of the large number of temperature and salinity data available to obtain a more realistic representation of the physical state of the ocean which positively impacts the simulation of the carbonate species in our model both at seasonal and inter-annual time scales.

15 We have assessed our results for the DIC and ALK against time series at HOT and BATS stations, where the physical assimilation leads to a smaller RMSE with the data collected at these stations. One remarkable outcome of our experiment is the improvement in alkalinity, particularly visible at BATS. Alkalinity is fully prognostic in the model and shares the same dynamical equation of salinity because we did not include any parameterization of carbonate shell formation in this simulation. Both variables are affected by transport and freshwater fluxes but salinity does feedback on water column stability while alkalinity is passively affected. This is why the assimilation of more realistic salinity data improves evaporation and the stability of the water column making ALK in TSREAN much more in agreement with data than in CTRL (Sect. 4, Fig. 7). The largest improvements in the carbonate variables appear within the first $400 \mathrm{~m}$ depth, where most of data are concentrated. The ocean carbonate system strongly depends on initial conditions, since, for instance, physical processes have little impact in modify-
BGD

$11,5399-5441,2014$

Impacts of physical data assimilation on the Global Ocean Carbonate System

L. Visinelli et al.

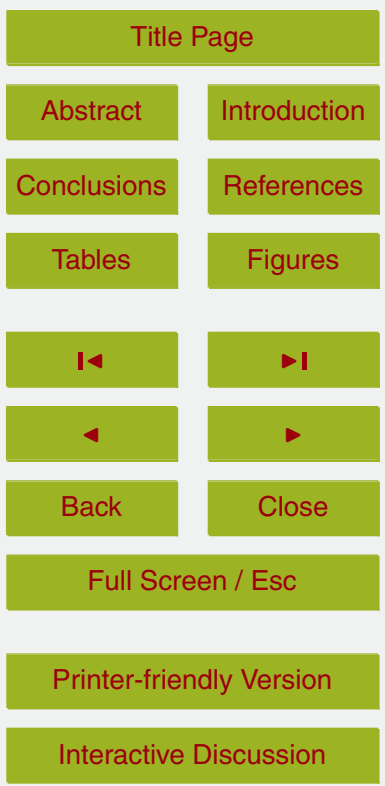


ing the alkalinity. We overcame this problem by modifying the initial conditions on ALK as discussed in Sect. 4, although a more sophisticated solution might be given in terms of assimilation of carbonate variables and will be investigated in a future work.

To assess the improvements of physical data assimilation at the global scale we 5 used the independent $p \mathrm{CO}_{2}$ fields from the SOCAT dataset (Sect. 5.1 and Table 5). We have shown that the assimilation of physics reduces the $p \mathrm{CO}_{2}$ biases in the major ocean regions both in terms of mean values and seasonal cycle, overall reducing the RMSE against the SOCAT climatology. We may hypothesize that this large scale improvement is due to a reduction of RMSE in the physics of the TSREAN simulation. It is fields, although the number of data are not sufficient to quantify this second hypothesis. Table 5 also reports the reduction of temperature and salinity RMSE against observations due to the assimilation and computed in the same oceanic regions as for $p \mathrm{CO}_{2}$. The changes are always negative because data assimilation improves the physical fields. In all the regions there is also a RMSE reduction for $p \mathrm{CO}_{2}$, with the only exceptions of the North Pacific and South Atlantic. In the South Atlantic, the comparison with the SOCAT data is limited to the South American coastal area, where most of the data are available, and this might limit the benefit of the assimilation of physical data. Furthermore, it is to be noted that the climatological nature of SOCAT does not sufficiently resolve the $p \mathrm{CO}_{2}$ higher frequency variability likely induced by the assimilation of the physical observations. It is also interesting to check if the relative improvement in $p \mathrm{CO}_{2}$ error (where found) may be explained by the direct effect of temperature according to Eq. (5). The largest improvements are found in the Indian, tropical and northern Atlantic, with a relative change of 4,4 and $3 \%$, respectively. If this was to be attributed to a direct effect of the corrected temperature, the corresponding change according to Eq. (5) and using the difference in temperature RMSE would all be around $1 \%$. The residual improvement is therefore to be attributed to the indirect effect of the physical transport processes due to the assimilation of physical data.
BGD

$11,5399-5441,2014$

Impacts of physical data assimilation on the Global Ocean Carbonate System

L. Visinelli et al.

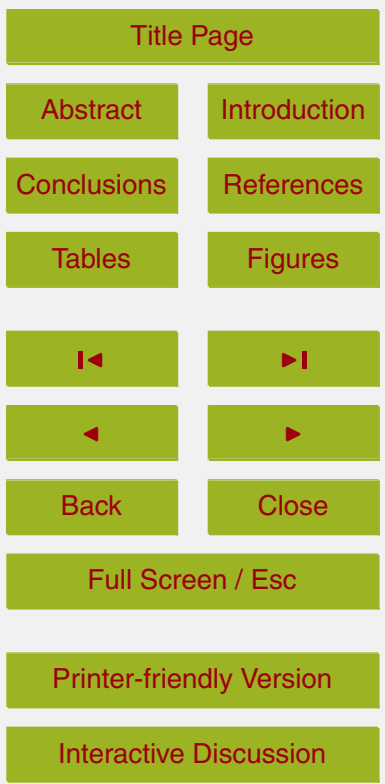


The results presented here are comparable with other works where data assimilation of carbonate variables was also used. The average absolute errors are comparable to those obtained by (Valsala and Maksyutov, 2010) who used an offline reanalysis with temperature and salinity assimilation, coupled offline with a biogeochemical model in 5 which $p \mathrm{CO}_{2}$ data from Takahashi and Sutherland (2007) were assimilated. Overall, our TSREAN run overestimates $p \mathrm{CO}_{2}$ in the Equatorial Pacific and Indian oceans, with an annual $40 \mu \mathrm{atm}$ error mean, and underestimates the $p \mathrm{CO}_{2}$ in the Equatorial Atlantic with an annual $60 \mu$ atm error mean. Here the error is lower than that obtained by (Valsala and Maksyutov, 2010) with a direct assimilation of carbonate data.

The work by While et al. (2012) is more similar to our experiments: the authors analyzed two runs over one single year, contrasting a control run with assimilation of temperature and salinity (as in our TSREAN experiment) with a further reanalysis run also including $p \mathrm{CO}_{2}$ data assimilation. However, no evaluation of the role of physical reanalysis was done in their case, opposed to our study where the emphasis is mainly

on the impact of a more realistic physics on the carbonate system. Although we are not assimilating the $p \mathrm{CO}_{2}$ data into the system, the RMSE obtained from our TSREAN run in the northern subtropical Atlantic basin is comparable to what obtained by While et al. (2012) when assimilating $p \mathrm{CO}_{2}$. We have thus obtained a considerable improvement over the quality of the reanalysis by assimilating temperature and salinity only. In the northern Atlantic, the $p \mathrm{CO}_{2}$ cycle reported by data significantly differ with respect to both our model runs and with those by While et al. (2012), because of the effect of biological consumptions which actively reduces the value of the $p \mathrm{CO}_{2}$ over summertime. Regardless of the assimilation of physical or chemical data, the $p \mathrm{CO}_{2}$ follows the temperature cycle. The stability of the water column is related to its stratification, which is strongly affected by the mechanism by which assimilation is performed. This fact has been showed at both BATS and HOT stations, where evaporation is reduced by means of the assimilated physics. Similarly, the largest reduction of the RMSE in the $p \mathrm{CO}_{2}$ is found in regions which show a corresponding decrease in the RMSE of salinity. This is particularly true in the tropical regions, the indian ocean, and the North Atlantic ocean.
BGD

$11,5399-5441,2014$

Impacts of physical

data assimilation on

the Global Ocean

Carbonate System

L. Visinelli et al.

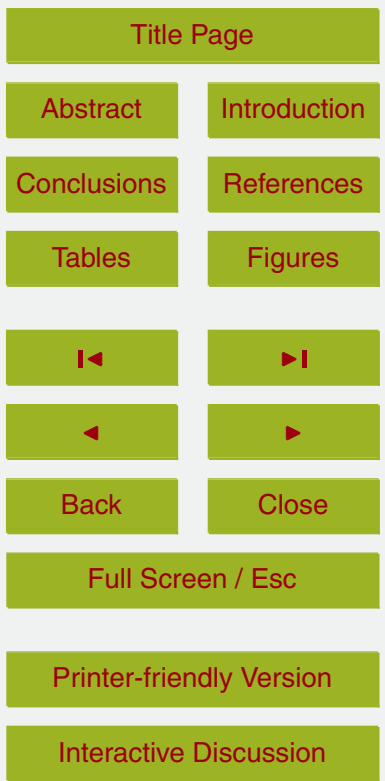


Comparing with previous works, we may infer that a combined simulation of the dynamical carbonate system with a physical reanalysis, either online or offline, leads to results that do not differ significantly from the direct assimilation of carbonate data for a system at low resolution (about $200 \mathrm{~km}$ ). It has to be confirmed if this result would 5 still be valid at eddy-permitting or eddy-resolving resolution, being the biological very sensitive to localized physical processes. As of now, global-scale network for collecting carbonate data is not expected to be operating in the coming years, while large surveys of physical data have been collected since the early 1990's and the ARGO monitoring observation network for the global physical ocean will likely be maintained in the next

future. Thus, the use of physical data coupled with a reliable biogeochemical model can be a good solution for simulating the carbonate system variables, as we have shown that the performance of such coupled model is comparable to when the fewer carbon data are assimilated. However, the possibility to use the available carbon data needs to be better exploited in the future, not only for validation purposes, but also in assimilation mode to reduce some of the biases of the biogeochemical models and improve the initial conditions.

Acknowledgements. The authors wish to thank the Centro Euro-Mediterraneo per i Cambiamenti Climatici for its financial and scientific support of the activities presented in this work. The implementation and the following improvements of the global ocean assimilation system were carried out in the framework of the GEOCARBON and MYOCEAN projects. The authors want to thank Simon Good (UK Met Office) for the support in the use of the EN3 dataset, and the TAO Project Office of NOAA/PMEL for letting the authors use the TAO/RAMA/PIRATA dataset.

\section{References}

Ballantyne, A. P., Alden, C. B., Miller, J. B., Tans, P. P., and White, J. W. C.: Increase in observed net carbon dioxide uptake by land and oceans during the past 50 years, Nature, 488, 70-72, 2012. 5401

Impacts of physical data assimilation on the Global Ocean Carbonate System

L. Visinelli et al.

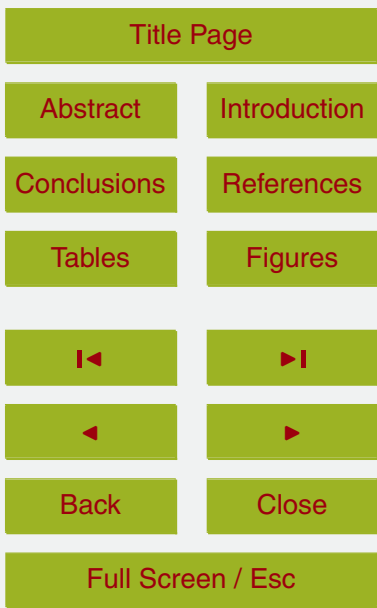

Printer-friendly Version

Interactive Discussion 
Blanke, B. and Delecluse, P.: Variability of the tropical atlantic-ocean simulated by a generalcirculation model with 2 different mixed-layer physics, J. Phys. Oceanogr., 23, 1363-1388, 1993. 5404

Canadell, J. G., Le Quéré, C., Raupach, M. R., Field, C. B., Buitenhuis, E. T., Ciais, P., Conway, T. J., Gillett, N. P., Houghton, R. A., and Marland, G.: Contributions to accelerating atmospheric $\mathrm{CO}_{2}$ growth from economic activity, carbon intensity, and efficiency of natural sinks., P. Natl. Acad. Sci. USA, 104, 18866-18870, 2007. 5401

Conway, T. J. and Tans, P. P.: Trends in Atmospheric Carbon Dioxide, available at: http://www. esrl.noaa.gov/gmd/ccgg/trends/, 2013. 5400

10 Crueger, T., Roeckner, E., Raddatz, T., Schnur, R., and Wetzel, P.: Ocean dynamics determine the response of oceanic $\mathrm{CO}_{2}$ uptake to climate change, Clim. Dynam., 31, 151-168, 2008. 5401

Dai, A. and Trenberth, K.: Estimates of freshwater discharge from continents: Latitudinal and seasonal variations, J. Hydrometeorol., 3, 660-687, 2002. 5404

15 Dee, D. P., Uppala, S. M., Simmons, A. J., Berrisford, P., Poli, P., Kobayashi, S., Andrae, U., Balmaseda, M. A., Balsamo, G., Bauer, P., Bechtold, P., Beljaars, A. C. M., van de Berg, L., Bidlot, J., Bormann, N., Delsol, C., Dragani, R., Fuentes, M., Geer, A. J., Haimberger, L., Healy, S. B., Hersbach, H., Hólm, E. V., Isaksen, L., Kållberg, P., Köhler, M., Matricardi, M., McNally, A. P., Monge-Sanz, B. M., Morcrette, J.-J., Park, B.-K., Peubey, C., de Rosnay, P., Tavolato, C., Thépaut, J.-N., and Vitart, F.: The ERA-Interim reanalysis: configuration and performance of the data assimilation system, Q. J. Roy. Meteor. Soc., 137, 553-597, 2011. 5404

Dobricic, S. and Pinardi, N.: An oceanographic three-dimensional variational data assimilation scheme, Ocean Model., 22, 89-105, 2008. 5406

Doney, S. C., Lindsay, K., Caldeira, K., Campin, J. M., Drange, H., Dutay, J. C., Follows, M., Gao, Y., Gnanadesikan, A., Gruber, N., Ishida, A., Joos, F., Madec, G., Maier-reimer, E., Marshall, J. C., Matear, R. J., Monfray, P., Mouchet, A., Najjar, R., Orr, J. C., Plattner, G. K., Sarmiento, J., Schlitzer, R., Slater, R., Totterdell, I. J., Weirig, M. F., Yamanaka, Y., and Yool, A.: Evaluating global ocean carbon models: the importance of realistic physics, Global

30 Biogeochem. Cy., 18, 3017, doi:10.1029/2003GB002150, 2004. 5401

Fichefet, T. and Maqueda, M. A. M.: Sensitivity of a global sea ice model to the treatment of ice thermodynamics and dynamics, J. Geophys. Res., 102, 12609-12646, 1997. 5403

BGD

11, 5399-5441, 2014

Impacts of physical

data assimilation on

the Global Ocean

Carbonate System

L. Visinelli et al.

Title Page

Abstract

Introduction

Conclusions

Tables

References

Figures

14

4

Back

Close

Full Screen / Esc

Printer-friendly Version

Interactive Discussion
>I

$>$ 
Gloor, M., Gruber, N., Sarmiento, J. L., Sabine, C. L., Feely, R. A., and Roedenbeck, C.: A first estimate of present and pre-industrial air-sea $\mathrm{CO}_{2}$ fluxes patterns based on ocean interior carbon measurements and models, Geophys. Res. Lett., 30, 1010, doi:10.1029/2002GL015594, 2003. 5401

5 Gruber, N., Gloor, M., Mikaloff Fletcher, S. E., Doney, S. C., Dutkiewicz, S., Follows, M. J., Gerber, M., Jacobson, A. R., Joos, F., Lindsay, K., Menemenlis, D., Mouchet, A., Mueller, S. A., Sarmiento, J. L., and Takahashi, T.: Oceanic sources, sinks, and transport of atmospheric $\mathrm{CO}_{2}$, Global Biogeochem. Cy., 23, GB1005, doi:10.1029/2008GB003349, 2009. 5401

Ingleby, B. and Huddleston, M.: Quality control of ocean temperature and salinity profiles historical and real-time data, J. Mar. Syst., 65, 158-175, 2007. 5406, 5409

Joos, F., Plattner, G.-K., Stocker, T. F., Marchal, O., and Schmittner, A.: Global warming and marine carbon cycle feedbacks an future atmospheric $p \mathrm{CO}_{2}$, Science, 284, 464-467, 1999. 5401

Key, R. M., Kozyr, A., Sabine, C. L., Lee, K., Wanninkhof, R., Bullister, J. L., Feely, R. A., 15 Millero, F. J., Mordy, C., and Peng, T. H.: A global ocean carbon climatology: results from Global Data Analysis Project (GLODAP), 18, GB4031, 2004. 5405

Large, W. and Yeager, S.: The global climatology of an interannually varying air-sea flux data set, Clim. Dynam., 33, 341-364, 2008. 5404

Le Quéré, C., Rodenbeck, C., Buitenhuis, E. T., Conway, T. J., Langenfelds, R., Gomez, A., Labuschagne, C., Ramonet, M., Nakazawa, T., Metzl, N., Gillett, N., and Heimann, M.: Saturation of the Southern Ocean $\mathrm{CO}_{2}$ sink due to recent climate change, Science, 316, 17351738, 2007. 5401

Le Quéré, C., Takahashi, T., Buitenhuis, E. T., Roedenbeck, C., and Sutherland, S. C.: Impact of climate change and variability on the global oceanic sink of $\mathrm{CO}_{2}$, Global Biogeochem. Cy., 24, GB4007, doi:10.1029/2009GB003599, 2010. 5401

Le Quéré, C., Andres, R. J., Boden, T., Conway, T., Houghton, R. A., House, J. I., Marland, G., Peters, G. P., van der Werf, G. R., Ahlström, A., Andrew, R. M., Bopp, L., Canadell, J. G., Ciais, P., Doney, S. C., Enright, C., Friedlingstein, P., Huntingford, C., Jain, A. K., Jourdain, C., Kato, E., Keeling, R. F., Klein Goldewijk, K., Levis, S., Levy, P., Lomas, M., Poulter, B., Raupach, M. R., Schwinger, J., Sitch, S., Stocker, B. D., Viovy, N., Zaehle, S., and Zeng, N.: The global carbon budget 1959-2011, Earth Syst. Sci. Data, 5, 165-185, doi:10.5194/essd-5165-2013, 2013. 5401
BGD

$11,5399-5441,2014$

Impacts of physical

data assimilation on

the Global Ocean

Carbonate System

L. Visinelli et al.

Title Page

Abstract

Introduction

Conclusions

Tables

References

Figures

14

4

Back

Full Screen / Esc

Printer-friendly Version

Interactive Discussion 
Le Quéré, C., Peters, G. P., Andres, R. J., Andrew, R. M., Boden, T., Ciais, P., Friedlingstein, P., Houghton, R. A., Marland, G., Moriarty, R., Sitch, S., Tans, P., Arneth, A., Arvanitis, A., Bakker, D. C. E., Bopp, L., Canadell, J. G., Chini, L. P., Doney, S. C., Harper, A., Harris, I., House, J. I., Jain, A. K., Jones, S. D., Kato, E., Keeling, R. F., Klein Goldewijk, K., Körtzinger, A., Koven, C., Lefèvre, N., Omar, A., Ono, T., Park, G.-H., Pfeil, B., Poulter, B., Raupach, M. R., Regnier, P., Rödenbeck, C., Saito, S., Schwinger, J., Segschneider, J., Stocker, B. D., Tilbrook, B., van Heuven, S., Viovy, N., Wanninkhof, R., Wiltshire, A., Zaehle, S., and Yue, C.: Global carbon budget 2013, Earth Syst. Sci. Data Discuss., 6, 689-760, doi:10.5194/essdd-6-689-2013, 2013. 5400, 5401

Locarnini, R. A., Mishonov, A. V., Antonov, J. I., Boyer, T. P., Garcia, H. E., Baranova, O. K., Zweng, M. M., and Johnson, D. R.: World Ocean Atlas 2009, Volume 1: Temperature, vol. NOAA Atlas NESDIS 68, US Government Printing Office, Washington DC, 2010. 5404, 5409

Madec, G. and Imbard, M.: A global ocean mesh to overcome the North Pole singularity, Clim. Dynam., 12, 381-388, 1996. 5403

Matear, R. and Hirst, A.: Climate change feedback on the future oceanic $\mathrm{CO}_{2}$ uptake, Tellus $\mathrm{B}$, 51, 722-733, 1999. 5401

Matsumoto, K., Sarmiento, J. L., Key, R. M., Aumont, O., Bullister, J. L., Caldeira, K., Campin, J.-M., Doney, S. C., Drange, H., Dutay, J.-C., Follows, M., Gao, Y., Gnanadesikan, A., Gruber, N., Ishida, A., Joos, F., Lindsay, K., Maier-Reimer, E., Marshall, J. C., Matear, R. J., Monfray, P., Mouchet, A., Najjar, R., Plattner, G.-K., Schlitzer, R., Slater, R., Swathi, P. S., Totterdell, I. J., Weirig, M.-F., Yamanaka, Y., Yool, A., and Orr, J. C.: Evaluation of ocean carbon cycle models with data-based metrics, Geophys. Res. Lett., 31, L07303, doi:10.1029/2003GL018970, 2004. 5401, 5402

McPhaden, M. J., Busalacchi, A. J., Cheney, R., Donguy, J.-R., Gage, K. S., Halpern, D., Ji, M., Julian, P., Meyers, G., Mitchum, G. T., Niiler, P. P., Picaut, J., Reynolds, R. W., Smith, N., and Takeuchi, K.: The tropical ocean-global atmosphere observing system: a decade of progress, J. Geophys. Res., 103, 14169-14240, doi:10.1029/97JC02906, 1998. 5409

Mehrbach, C., Culberson, C. H., Hawley, J. E., and Pytkowicz, R. M.: Measurement of the apparent dissociation constants of carbonic acid in seawater at atmospheric pressure Measurement of the apparent dissociation constants of carbonic acid in seawater at atmospheric pressure measurement of the apparent dissociation cntant of carbonic acid in seawater at atmospheric pressure, Limnol. Oceanogr., 18, 897-907, 1973. 5407

Impacts of physical data assimilation on the Global Ocean

Carbonate System

L. Visinelli et al.

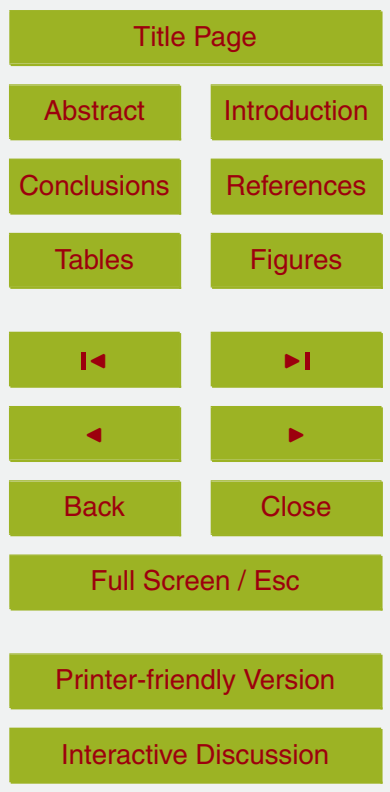


Mikaloff Fletcher, S. E., Gruber, N., Jacobson, A. R., Gloor, M., Doney, S. C., Dutkiewicz, S., Gerber, M., Follows, M., Joos, F., Lindsay, K., Menemenlis, D., Mouchet, A., Mueller, S. A., and Sarmiento, J. L.: Inverse estimates of the oceanic sources and sinks of natural $\mathrm{CO}_{2}$ and the implied oceanic carbon transport, Global Biogeochem. Cy., 21, GB1010, 5 doi:10.1029/2006GB002751, 2007. 5401

Reynolds, R. W., Smith, T. M., Liu, C., Chelton, D. B., Casey, K. S., and Schlax, M. G.: Daily high-resolution-blended analyses for sea surface temperature, J. Climate, 20, 5473-5496, 2007. 5409

Ridgwell, A., Hargreaves, J. C., Edwards, N. R., Annan, J. D., Lenton, T. M., Marsh, R., Yool, A., and Watson, A.: Marine geochemical data assimilation in an efficient Earth System Model of global biogeochemical cycling, Biogeosciences, 4, 87-104, doi:10.5194/bg-4-87-2007, 2007. 5402

Sabine, C. L., Hankin, S., Koyuk, H., Bakker, D. C. E., Pfeil, B., Olsen, A., Metzl, N., Kozyr, A., Fassbender, A., Manke, A., Malczyk, J., Akl, J., Alin, S. R., Bellerby, R. G. J., Borges, A., Boutin, J., Brown, P. J., Cai, W.-J., Chavez, F. P., Chen, A., Cosca, C., Feely, R. A., GonzálezDávila, M., Goyet, C., Hardman-Mountford, N., Heinze, C., Hoppema, M., Hunt, C. W., Hydes, D., Ishii, M., Johannessen, T., Key, R. M., Körtzinger, A., Landschützer, P., Lauvset, S. K., Lefèvre, N., Lenton, A., Lourantou, A., Merlivat, L., Midorikawa, T., Mintrop, L., Miyazaki, C., Murata, A., Nakadate, A., Nakano, Y., Nakaoka, S., Nojiri, Y., Omar, A. M., Padin, X. A., Park, G.-H., Paterson, K., Perez, F. F., Pierrot, D., Poisson, A., Ríos, A. F., Salisbury, J., Santana-Casiano, J. M., Sarma, V. V. S. S., Schlitzer, R., Schneider, B., Schuster, U., Sieger, R., Skjelvan, I., Steinhoff, T., Suzuki, T., Takahashi, T., Tedesco, K., Telszewski, M., Thomas, H., Tilbrook, B., Vandemark, D., Veness, T., Watson, A. J., Weiss, R., Wong, C. S., and Yoshikawa-Inoue, $\mathrm{H}$.: Surface Ocean $\mathrm{CO}_{2}$ Atlas (SOCAT) gridded data products, Earth Syst. Sci. Data, 5, 145-153, doi:10.5194/essd-5-145-2013, 2013. 5409, 5439

Sarmiento, J. L., and Le Quéré, C.: Oceanic carbon dioxide uptake in a model of century-scale global warming, Science, 274, 1346-1350, 1996. 5401

Sarmiento, J. L., Gloor, M., Gruber, N., Beaulieu, C., Jacobson, A. R., Mikaloff Fletcher, S. E., Pacala, S., and Rodgers, K.: Trends and regional distributions of land and ocean carbon sinks, Biogeosciences, 7, 2351-2367, doi:10.5194/bg-7-2351-2010, 2010. 5401

Storto, A., Dobricic, S., Masina, S., and Di Pietro, P.: Assimilating along-track altimetric observations through local hydrostatic adjustment in a global ocean variational assimilation system, Mon. Weather Rev., 139, 738-754, 2011. 5406

Impacts of physical data assimilation on the Global Ocean Carbonate System

L. Visinelli et al.

Title Page

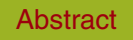

Introduction

Conclusions

Tables

References

Figures

14

4

Back

Full Screen / Esc

Printer-friendly Version

Interactive Discussion 
Takahashi, T. and Sutherland, S. C.: Global ocean surface water partial pressure of $\mathrm{CO}_{2}$ database: measurements performed during 1968-2007, ORNL/CDIAC-152 NDP-088a, Lamont-Doherty Earth Observatory, Columbia University, Palisades, NY 10964, 2007. 5401, 5420

5 Takahashi, T., Olafsson, J., Goddard, J. G., Chipman, D. W., and Sutherland, S. C.: Seasonal variation of $\mathrm{CO} 2$ and nutrients in the high-latitude surface oceans: a comparative study, Global Biogeochem. Cy., 7, 843-878, doi:10.1029/93GB02263, 1993. 5408

Valsala, V. and Maksyutov, S.: Simulation and assimilation of global ocean $p \mathrm{CO}_{2}$ and air-sea $\mathrm{CO}_{2}$ fluxes using ship observations of surface ocean $p \mathrm{CO}_{2}$ in a simplified biogeochemical 10 offline model, Tellus B, 821-840, 2010. 5402, 5420

Vichi, M. and Masina, S.: Skill assessment of the PELAGOS global ocean biogeochemistry model over the period 1980-2000, Biogeosciences, 6, 2333-2353, doi:10.5194/bg-6-23332009, 2009. 5405, 5412

Vichi, M., Masina, S., and Navarra, A.: A generalized model of pelagic biogeochemistry for 15 the global ocean ecosystem, Part II: Numerical simulations, J. Marine Syst., 64, 110-134, 2007a. 5405

Vichi, M., Pinardi, N., and Masina, S.: A generalized model of pelagic biogeochemistry for the global ocean ecosystem. Part I: theory, J. Marine Syst., 64, 89-109, 2007b. 5405

Vichi, M., Manzini, E., Fogli, P., Alessandri, A., Patara, L., Scoccimarro, E., Masina, S., and

20 Navarra, A.: Global and regional ocean carbon uptake and climate change: sensitivity to a substantial mitigation scenario, Clim. Dynam., 37, 1929-1947, doi:10.1007/s00382-0111079-0, 2011. 5401

Wanninkhof, R.: Relationship between windspeed and gas exchange over the ocean, J. Geophys. Res., 97, 7373-7382, 1992. 5402, 5406

Watson, A. J. and Orr, J. C.: Ocean Biogeochemistry, Global Change - The IGBP Series (closed), Springer, Berlin, Heidelberg, 2003. 5401

Weiss, R.: Carbon dioxide in water and seawater: the solubility of a non-ideal gas, Mar. Chem., 203-215, 1974. 5408

While, J., Totterdell, I., and Martin, M.: Assimilation of $p \mathrm{CO}_{2}$ data into a global cou30 pled physical-biogeochemical ocean model, J. Geophys. Res.-Oceans, 117, C03037, doi:10.1029/2010JC006815, 2012. 5402, 5420

Zeebe, R. E. and Wolf-Gladrow, D. A.: $\mathrm{CO}_{2}$ in Seawater: Equilibrium, Kinetics, Isotopes, Oceanography Book Series, vol. 65, Elsevier, Amsterdam, 2001. 5401, 5407

Impacts of physical

data assimilation on

the Global Ocean

Carbonate System

L. Visinelli et al.

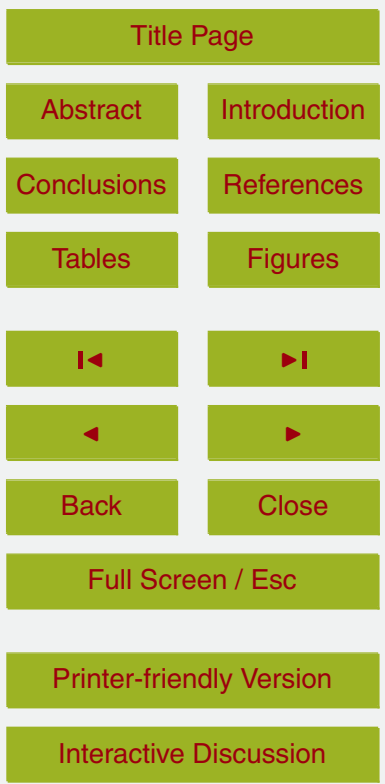


Table 1. Experiment list.

\begin{tabular}{lccc}
\hline & CTRL & TSREAN & TSREAN_NB \\
\hline T\&S Assimilation & No & Yes & Yes \\
Biology included & Yes & Yes & No \\
\hline
\end{tabular}

BGD

11, 5399-5441, 2014

Impacts of physical

data assimilation on

the Global Ocean

Carbonate System

L. Visinelli et al.

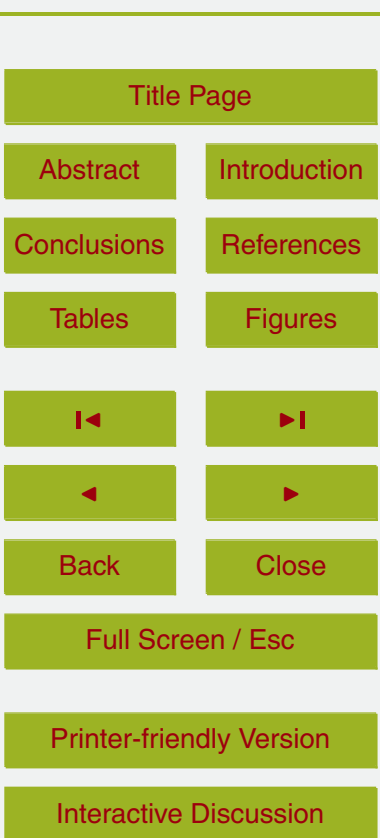


Table 2. Mean value and standard deviation of temperature (TEM, top table) and salinity (SAL, bottom table) at BATS and HOT locations, respectively for CTRL, TSREAN, and DATA time series. Also reported are the RMSE and the correlation between CTRL and data, and between TSREAN and data. For temperature and salinity, statistics are computed both over the first ten meters (SURFACE) and over the whole vertical profile (COLUMN).

\begin{tabular}{lcccccccccc}
\hline TEM & \multicolumn{3}{c}{ MEAN $\left({ }^{\circ} \mathrm{C}\right)$} & \multicolumn{3}{c}{ STDEV $\left({ }^{\circ} \mathrm{C}\right)$} & \multicolumn{2}{c}{ RMSE $\left({ }^{\circ} \mathrm{C}\right)$} & & $r$ \\
\hline STATION & CTRL & TSREAN & DATA & CTRL & TSREAN & DATA & CTRL & TSREAN & CTRL & TSREAN \\
\hline SURFACE & & & & & & & & & & \\
\hline HOT & 25.1 & 25.0 & 24.9 & 1.3 & 1.3 & 1.2 & 0.37 & 0.35 & 0.99 & 0.98 \\
BATS & 23.8 & 23.3 & 24.0 & 2.7 & 3.0 & 3.0 & 0.65 & 0.59 & 0.99 & 0.99 \\
\hline COLUMN & & & & & & & & & & \\
\hline HOT & 15.0 & 14.8 & 17.0 & 9.07 & 9.11 & 8.52 & 1.0 & 0.8 & 0.99 & 0.99 \\
BATS & 15.7 & 15.1 & 18.0 & 7.9 & 7.5 & 6.7 & 1.8 & 0.6 & 0.95 & 0.96 \\
\hline SAL & & MEAN & & & STDEV & & & RMSE & & $r$ \\
\hline STATION & CTRL & TSREAN & DATA & CTRL & TSREAN & DATA & CTRL & TSREAN & CTRL & TSREAN \\
\hline SURFACE & & & & & & & & & & \\
\hline HOT & 35.4 & 35.2 & 35.1 & 0.08 & 0.15 & 0.20 & 0.37 & 0.17 & 0.55 & 0.74 \\
BATS & 36.4 & 36.6 & 36.6 & 0.07 & 0.11 & 0.16 & 0.21 & 0.15 & 0.63 & 0.47 \\
\hline COLUMN & & & & & & & & & & \\
\hline HOT & 35.0 & 34.9 & 34.9 & 0.47 & 0.39 & 0.41 & 0.18 & 0.13 & 0.95 & 0.97 \\
BATS & 36.0 & 36.1 & 35.8 & 0.74 & 0.83 & 0.78 & 0.32 & 0.10 & 0.94 & 0.95 \\
\hline
\end{tabular}

\section{BGD}

$11,5399-5441,2014$

Impacts of physical data assimilation on

the Global Ocean

Carbonate System

L. Visinelli et al.

\section{Title Page}

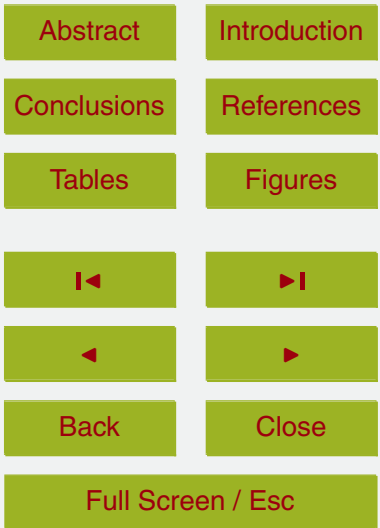

Printer-friendly Version

Interactive Discussion 
Table 3. Mean value and standard deviation of the MLD at BATS and HOT locations, respectively for CTRL, TSREAN, and DATA time series. Also reported are the RMSE and the correlation between CTRL and data, and between TSREAN and data.

\begin{tabular}{lcccccccccc}
\hline MLD & \multicolumn{3}{c}{ MEAN $(m)$} & \multicolumn{3}{c}{ STDEV $(m)$} & \multicolumn{2}{c}{ RMSE $(m)$} & \multicolumn{1}{c}{$r$} \\
\hline STATION & CTRL & TSREAN & DATA & CTRL & TSREAN & DATA & CTRL & TSREAN & CTRL & TSREAN \\
\hline HOT & 44 & 45 & 31 & 23 & 23 & 19 & 27 & 25 & 0.62 & 0.67 \\
BATS & 89 & 67 & 66 & 84 & 68 & 63 & 69 & 34 & 0.88 & 0.93 \\
\hline
\end{tabular}

Impacts of physical data assimilation on the Global Ocean Carbonate System

L. Visinelli et al.

Title Page

Abstract Introduction

Conclusions

References

Tables

Figures

14

$>$ I

4

Back

Close

Full Screen / Esc

Printer-friendly Version

Interactive Discussion 
Table 4. Same as Table 2, but for DIC (top table) and ALK (bottom table).

\begin{tabular}{|c|c|c|c|c|c|c|c|c|c|c|}
\hline \multirow{2}{*}{$\frac{\text { DIC }}{\text { STATION }}$} & \multicolumn{3}{|c|}{ MEAN $\left(\mu \mathrm{mol} \mathrm{kg}^{-1}\right)$} & \multicolumn{3}{|c|}{ STDEV $\left(\mu \mathrm{mol} \mathrm{kg}^{-1}\right)$} & \multicolumn{2}{|c|}{ RMSE $\left(\mu \mathrm{mol} \mathrm{kg}{ }^{-1}\right)$} & \multicolumn{2}{|r|}{$r$} \\
\hline & CTRL & TSREAN & DATA & CTRL & TSREAN & DATA & CTRL & TSREAN & CTRL & TSREAN \\
\hline \multicolumn{11}{|l|}{ SURFACE } \\
\hline HOT & 1950 & 1970 & 1980 & 21 & 27 & 17 & 27 & 19 & 0.82 & 0.72 \\
\hline BATS & 2060 & 2040 & 2050 & 39 & 27 & 19 & 33 & 16 & 0.71 & 0.86 \\
\hline \multicolumn{11}{|l|}{ COLUMN } \\
\hline HOT & 2100 & 2110 & 2120 & 160 & 150 & 140 & 32 & 28 & 0.99 & 0.99 \\
\hline BATS & 2110 & 2100 & 2070 & 44 & 47 & 26 & 33 & 17 & 0.85 & 0.88 \\
\hline ALK & \multicolumn{3}{|c|}{ MEAN $\left(\mu \mathrm{molkg}^{-1}\right)$} & \multicolumn{3}{|c|}{ STDEV $\left(\mu \mathrm{molkg}^{-1}\right)$} & \multicolumn{2}{|c|}{ RMSE $\left(\mu \mathrm{molkg}{ }^{-1}\right)$} & \multicolumn{2}{|r|}{$r$} \\
\hline STATION & CTRL & TSREAN & DATA & CTRL & TSREAN & DATA & CTRL & TSREAN & CTRL & TSREAN \\
\hline \multicolumn{11}{|l|}{ SURFACE } \\
\hline HOT & 2300 & 2320 & 2310 & 14 & 22 & 15 & 13 & 21 & 0.60 & 0.45 \\
\hline BATS & 2470 & 2380 & 2390 & 42 & 9 & 11 & 96 & 15 & 0.20 & 0.22 \\
\hline \multicolumn{11}{|l|}{ COLUMN } \\
\hline HOT & 2310 & 2320 & 2320 & 40 & 36 & 42 & 31 & 29 & 0.93 & 0.87 \\
\hline BATS & 2410 & 2360 & 2390 & 70 & 21 & 13 & 84 & 20 & 0.60 & 0.58 \\
\hline
\end{tabular}

\section{BGD}

11, 5399-5441, 2014

Impacts of physical data assimilation on the Global Ocean Carbonate System

L. Visinelli et al.

\section{Title Page}

Abstract

Introduction

Conclusions

References

Tables

Figures

14

Back

Close

Full Screen / Esc

Printer-friendly Version

Interactive Discussion 
Table 5. Values of the mean (here MEAN) and the standard deviation (here STDEV), of the climatological $p \mathrm{CO}_{2}$ for the SOCAT dataset, the control run (CTRL) and the assimilation run (TSREAN), together with the difference between the TSREAN and CTRL RMSE with the SOCAT dataset. For the RMSE differences, we have shown the results for the $p \mathrm{CO}_{2}$, the SSS, and the SST. The "south" Atlantic (S ATL) and Pacific (S PAC) regions are defined as the $60^{\circ} \mathrm{S}$ to $20^{\circ} \mathrm{S}$ latitude strip in the respective basin, the "tropical" regions (T ATL and T PAC) lie in the $20^{\circ} \mathrm{S}$ to $20^{\circ} \mathrm{N}$ latitude strip, and the "north" regions (N ATL and N PAC) lie in the $20^{\circ} \mathrm{N}$ to $60^{\circ} \mathrm{N}$ latitude strip. The Antarctic Circumpolar Current is defined here as the region lying below $60^{\circ} \mathrm{S}$, and the "Indian" region is defined as the Indian basin with latitude above $40^{\circ} \mathrm{S}$.

\begin{tabular}{cccccccccc}
\hline & \multicolumn{3}{c}{$p \mathrm{CO}_{2}$ MEAN $(\mu \mathrm{atm})$} & \multicolumn{3}{c}{$p \mathrm{CO}_{2}$ STDEV $(\mu \mathrm{atm})$} & \multicolumn{3}{c}{ RMSE $_{\text {TSREAN }}-\mathrm{RMSE}_{\mathrm{CTRL}}$} \\
\hline REGION & $\mathrm{CTRL}$ & TSREAN & DATA & $\mathrm{CTRL}$ & TSREAN & DATA & $p \mathrm{CO}_{2}(\mu \mathrm{atm})$ & $\mathrm{SSS}$ & $\mathrm{SST}\left({ }^{\circ} \mathrm{C}\right)$ \\
\hline INDIAN & 316 & 346 & 352 & 16 & 24 & 26 & -11.9 & -0.06 & -0.34 \\
S PAC & 320 & 334 & 337 & 22 & 21 & 21 & -3.4 & -0.05 & -0.18 \\
T PAC & 348 & 370 & 371 & 36 & 43 & 35 & -4.1 & -0.03 & -0.22 \\
N PAC & 342 & 356 & 349 & 26 & 21 & 20 & 1.8 & -0.05 & -0.28 \\
S ATL & 349 & 363 & 347 & 14 & 14 & 28 & 0.7 & -0.03 & -0.24 \\
T ATL & 312 & 325 & 370 & 17 & 22 & 22 & -10.8 & -0.06 & -0.27 \\
N ATL & 322 & 337 & 354 & 22 & 23 & 22 & -8.5 & -0.05 & -0.26 \\
ACC & 364 & 360 & 340 & 7 & 7 & 30 & -0.9 & -0.04 & -0.28
\end{tabular}

Impacts of physical data assimilation on the Global Ocean Carbonate System

L. Visinelli et al.

\section{Title Page}

\section{Abstract} Introduction

Conclusions References

Tables Figures

14

4

Back

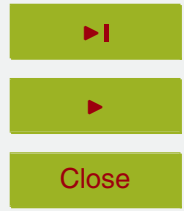

Full Screen / Esc

Printer-friendly Version

Interactive Discussion 
(a)

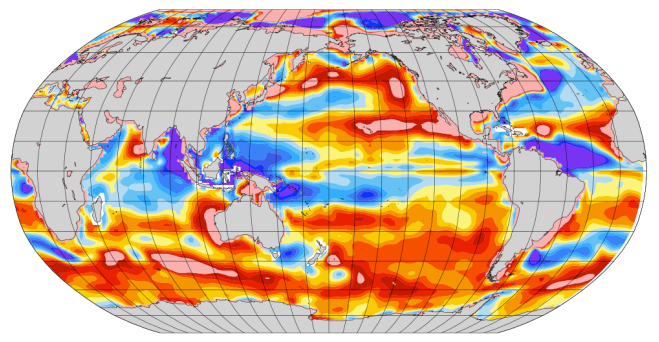

(b)

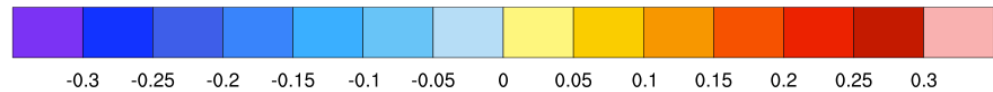

(c)

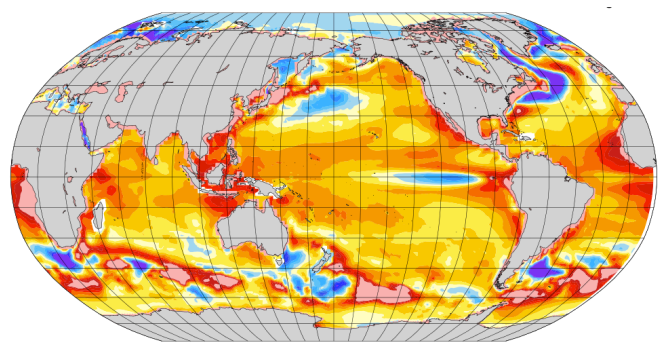

(d)
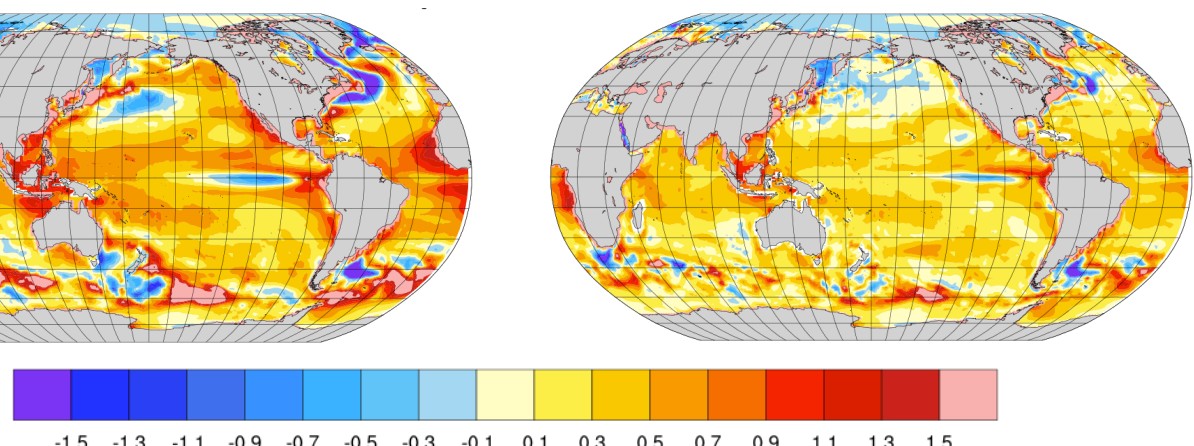

Fig. 1. Top panel: difference between the climatological sea surface salinity (SSS) reported in the climatological SSS from the Levitus reanalysis and CTRL (a) or TSREAN (b). Bottom panel: as in the top panel but for the climatological SST reanalysis reported by Reynolds over the period $1992-2009$ (in ${ }^{\circ} \mathrm{C}$ ).

\section{BGD}

$11,5399-5441,2014$

Impacts of physical data assimilation on the Global Ocean Carbonate System

L. Visinelli et al.

\section{Title Page}

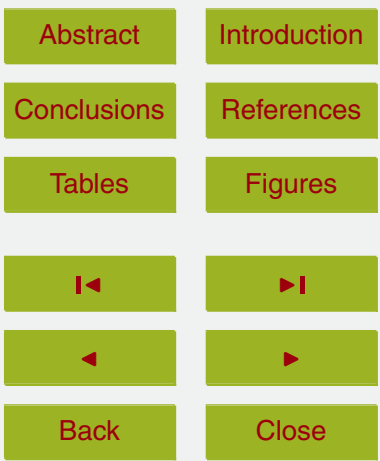

Full Screen / Esc

Printer-friendly Version

Interactive Discussion 
(a)

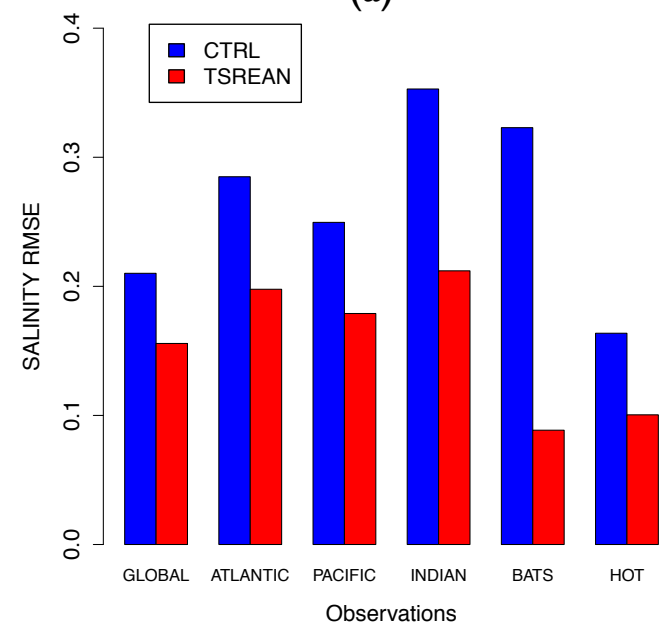

(b)

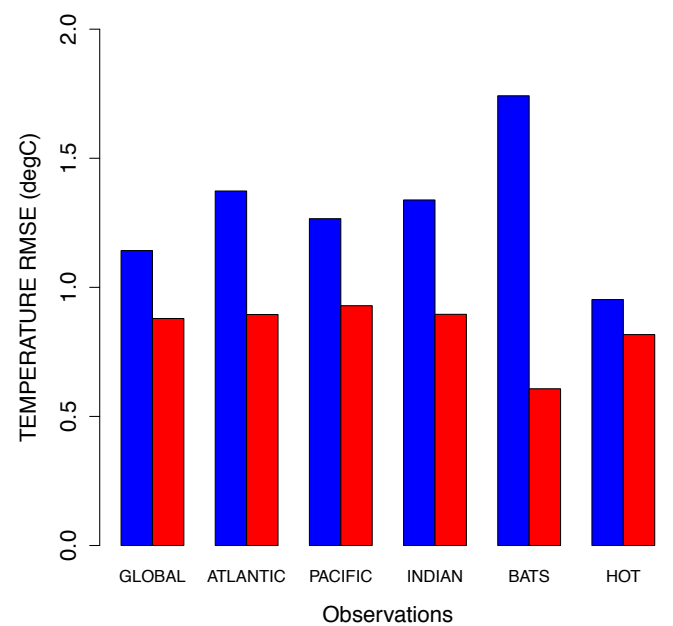

Fig. 2. The root-mean square value of the salinity misfits (a) and of the temperature misfits (b), taken between the observed data and the simulation for CTRL (in blue) and TSREAN (in red), for different oceanic basins (Global, Atlantic, Pacific, Indian) or stations (BATS, HOT). In the three basins, the RMSE is computed considering data over the whole water column from the PIRATA (Atlantic), TOGA-TAO (Pacific), or RAMA (Indian) floats, while in the two stations the CTD floats have been considered.

BGD

$11,5399-5441,2014$

Impacts of physical data assimilation on

the Global Ocean

Carbonate System

L. Visinelli et al.

\section{Title Page}

\section{Abstract}

Conclusions

Tables

14

Back
Introduction

References

Figures

-I

$>$

Close

\section{Full Screen / Esc}

Printer-friendly Version

Interactive Discussion 
(a)

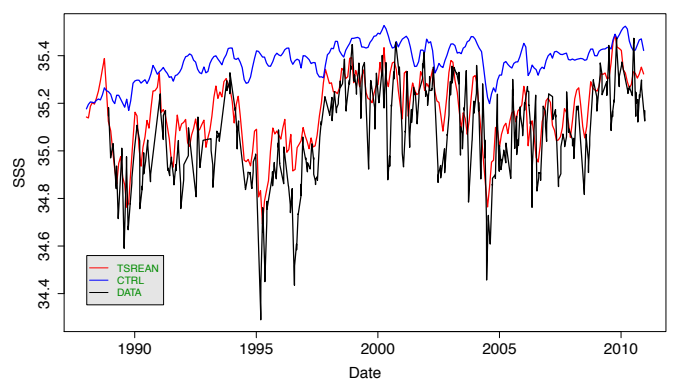

(c)

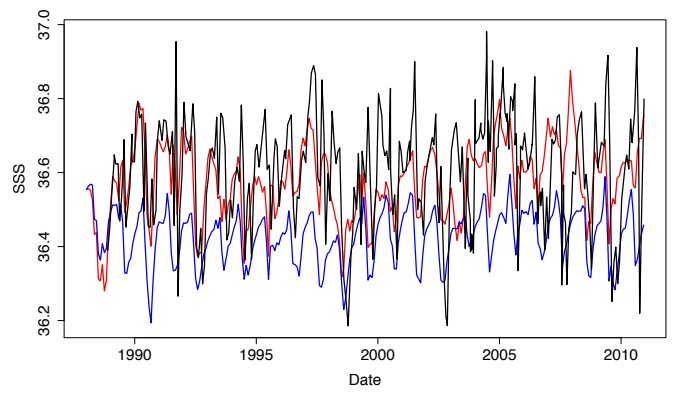

(b)

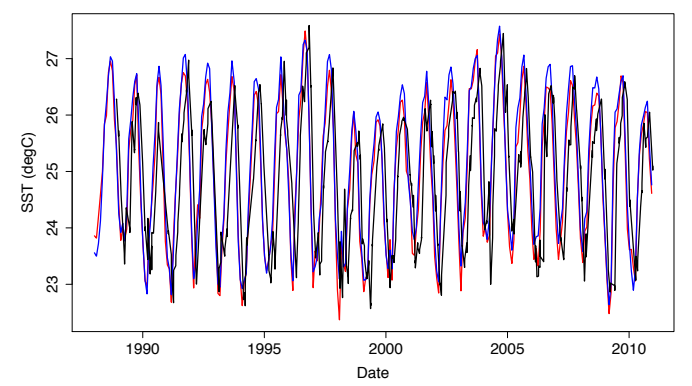

(d)

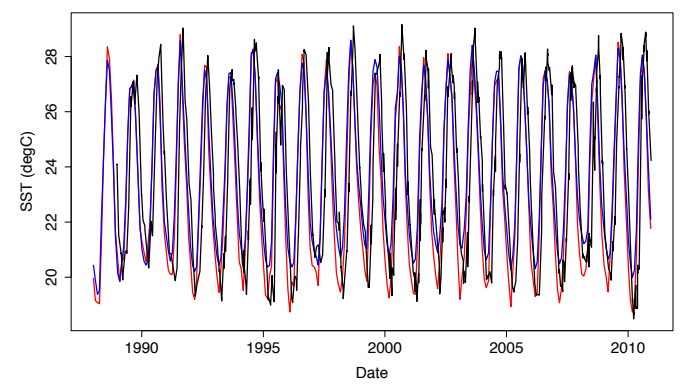

BGD

11, 5399-5441, 2014

Impacts of physical data assimilation on the Global Ocean Carbonate System

L. Visinelli et al.

Title Page

Abstract Introduction

Conclusions

References

Tables

Figures

14

>

4

Back

Close

Fig. 3. Sea surface salinity (a, c) and temperature (b, d) at HOT (top) and BATS (bottom) from the control simulation (blue line), the assimilation reanalysis (red line), and the data collected on the site (black line).

\section{Full Screen / Esc}

Printer-friendly Version

Interactive Discussion 
(a)

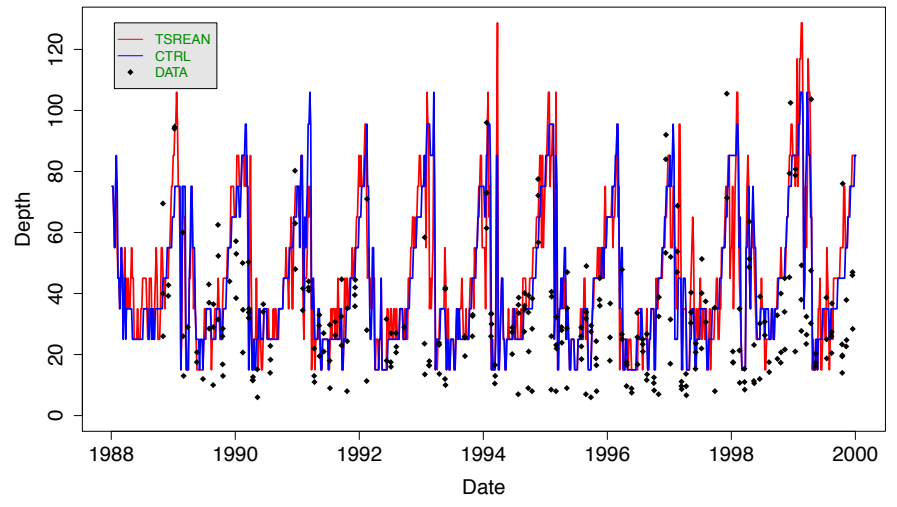

(b)

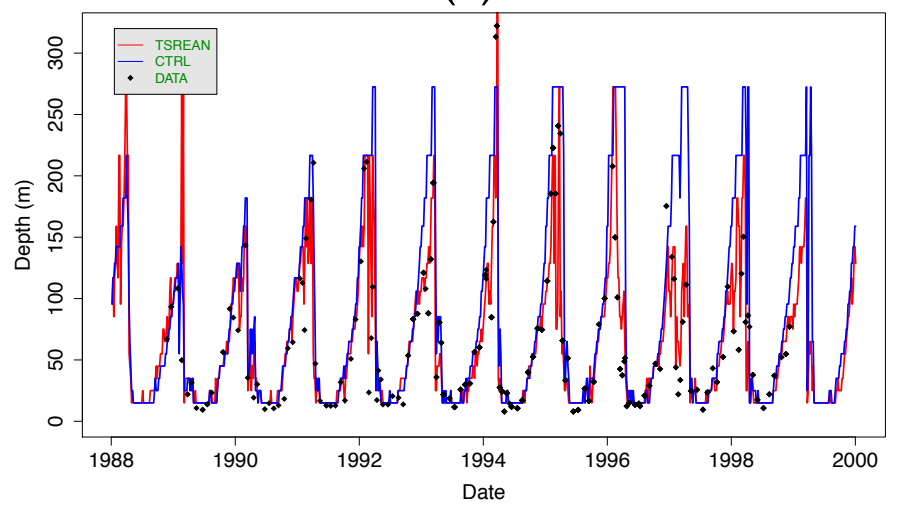

Fig. 4. Comparison between the MLD data reported from JGOFS, CTRL, TSREAN, for the period 1989-2000 at HOT (a) and BATS (b).

\section{BGD}

11, 5399-5441, 2014

Impacts of physical data assimilation on the Global Ocean Carbonate System

L. Visinelli et al.

\section{Title Page}

\section{Abstract}

Introduction

Conclusions

References

Tables

Figures

14

I

4

Back

Close

Full Screen / Esc

Printer-friendly Version

Interactive Discussion 
(a)

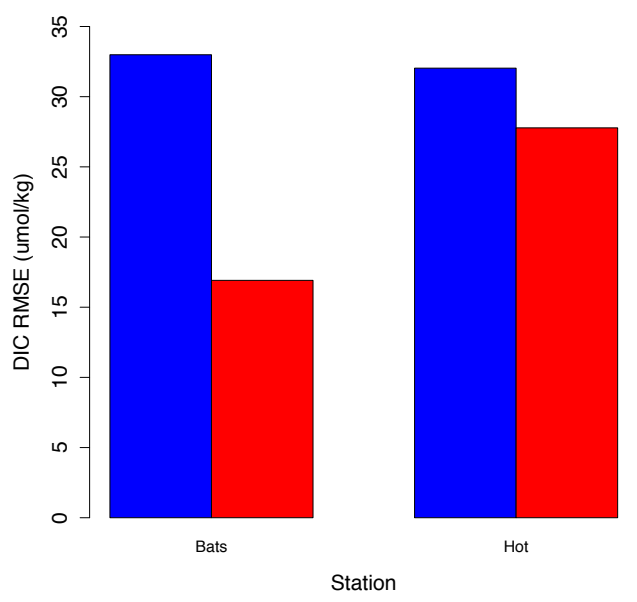

(b)

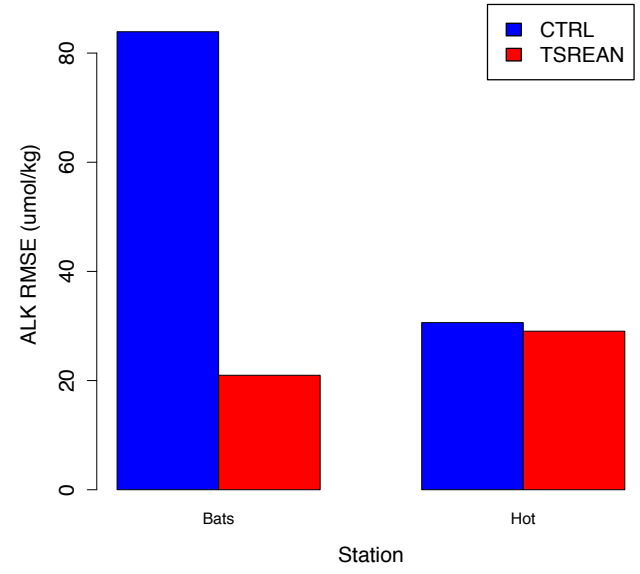

Fig. 5. RMSE for DIC (a) and of ALK (b) between the data collected over the whole water column at BATS and HOT stations and CTRL (Blue) or TSREAN (Red).

\section{BGD}

$11,5399-5441,2014$

Impacts of physical

data assimilation on

the Global Ocean

Carbonate System

L. Visinelli et al.

Title Page

Abstract

Introduction

Conclusions

References

Tables

Figures

14

-I

4

Back

Close

Full Screen / Esc

Printer-friendly Version

Interactive Discussion 
(a)

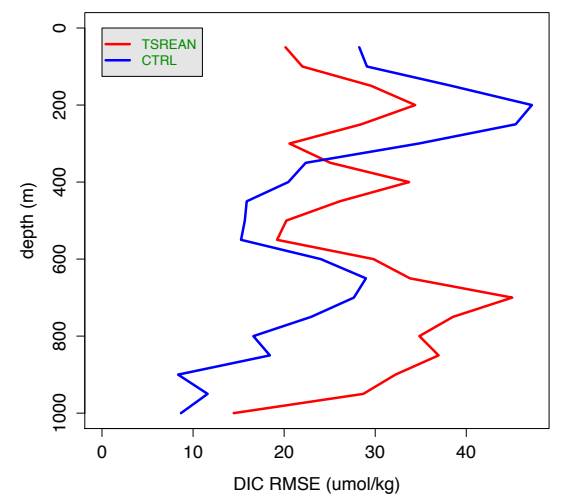

(c)

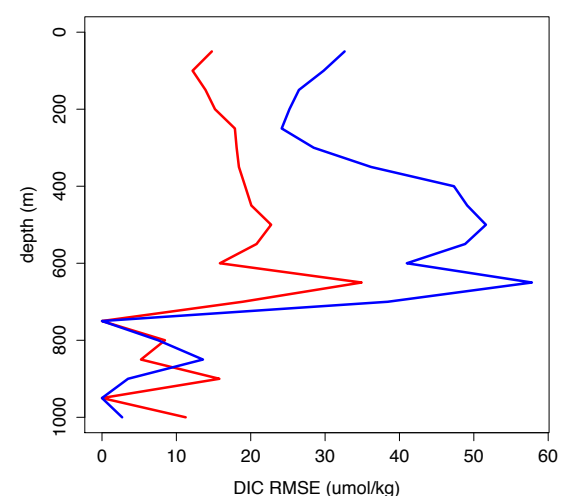

(b)

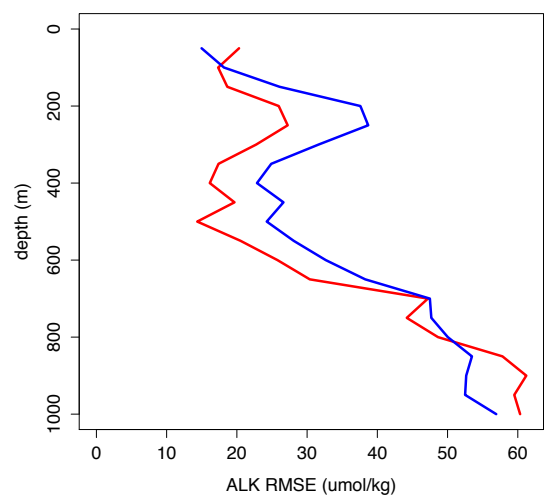

(d)

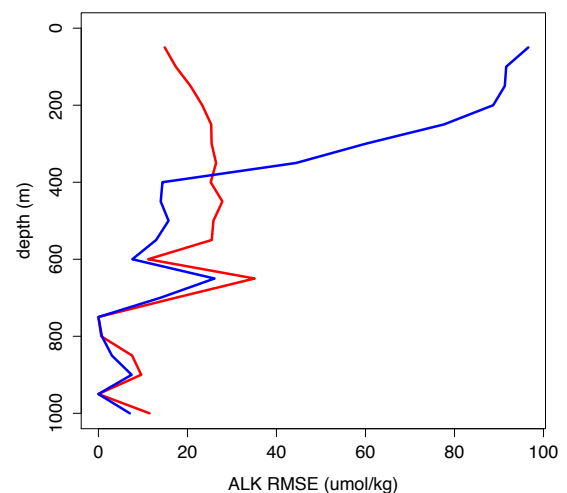

BGD

11, 5399-5441, 2014

Impacts of physical data assimilation on the Global Ocean Carbonate System

L. Visinelli et al.

Title Page

Abstract

Introduction

Conclusions

References

Tables

Figures

14

$>$ I

4

Back

Close

\section{Full Screen / Esc}

Printer-friendly Version

Interactive Discussion 
(a)

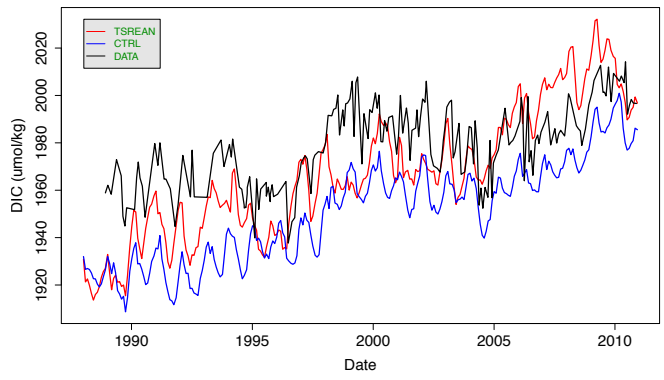

(c)

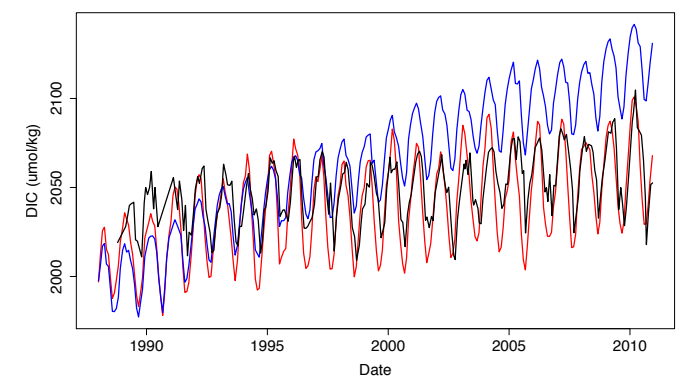

(b)

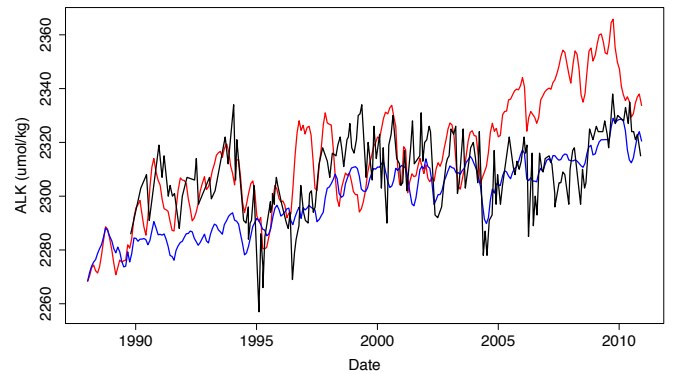

(d)

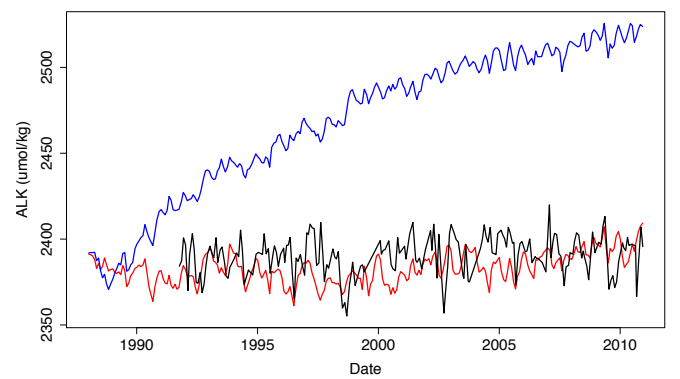

BGD

11, 5399-5441, 2014

Impacts of physical data assimilation on the Global Ocean Carbonate System

L. Visinelli et al.

\section{Title Page}

\section{Abstract}

Introduction

Conclusions

References

Tables

Figures

14

4

Back

Close

\section{Full Screen / Esc}

Printer-friendly Version (bottom) from the control simulation (blue line), the assimilation reanalysis (red line), and the data collected on the site (black line). 
(a)

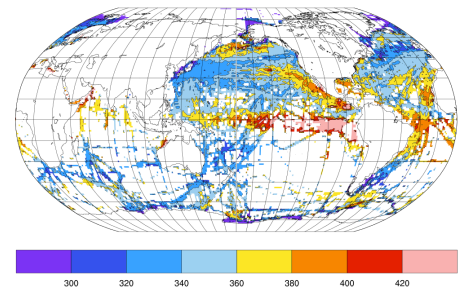

(b)

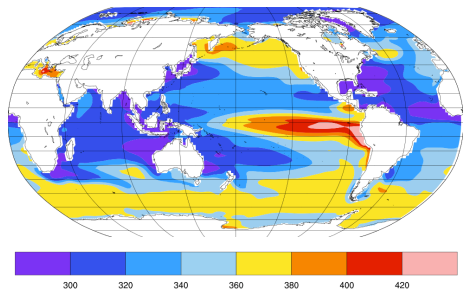

(d)

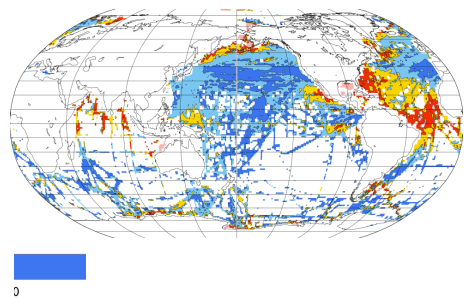

(c)

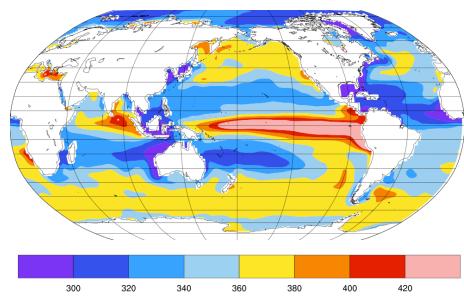

(e)

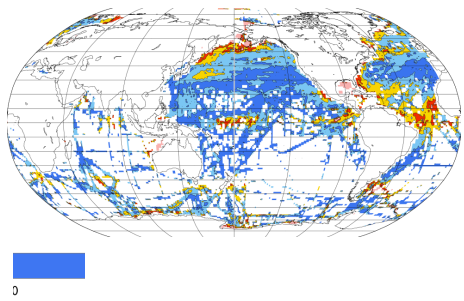

Fig. 8. (a) Climatological map of the $p \mathrm{CO}_{2}$ reported by Sabine et al. (2013) for the period 19682007, plotted over a $1^{\circ} \times 1^{\circ}$ regular grid. (b) Climatological $p \mathrm{CO}_{2}$ for CTRL, plotted over the ORCA2 grid. (c) Climatological $p \mathrm{CO}_{2}$ for TSREAN, plotted over the ORCA2 grid. (d) Average of the difference between the monthly $p \mathrm{CO}_{2}$ climatology for CTRL and the SOCAT dataset. (e) Average of the difference between the monthly $p \mathrm{CO}_{2}$ climatology for TSREAN and the SOCAT dataset.
Impacts of physical data assimilation on the Global Ocean Carbonate System

L. Visinelli et al.

\section{Title Page}

\section{Abstract} Introduction

Conclusions References

Tables

Figures

14

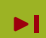

4

Back

Close

Full Screen / Esc

Printer-friendly Version

Interactive Discussion 
(a)

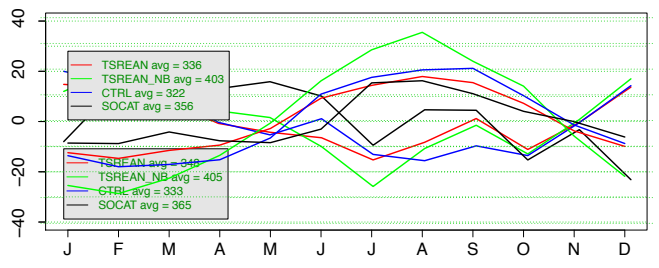

(c)

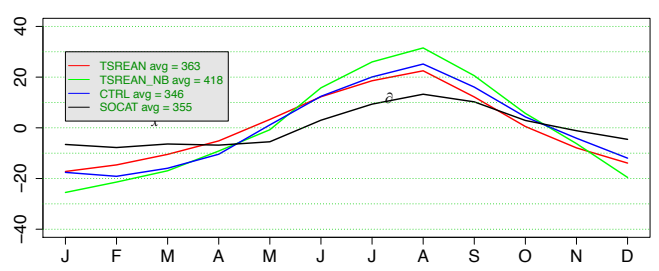

(b)

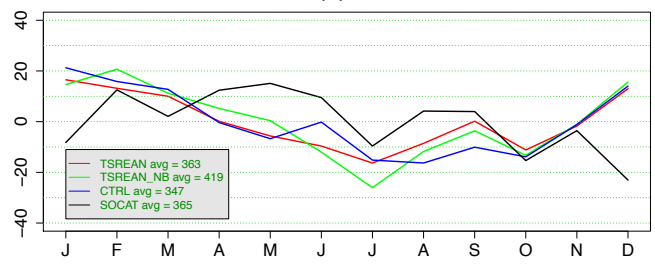

(d)

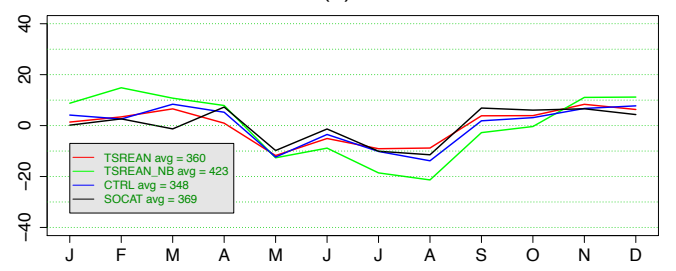

(e)

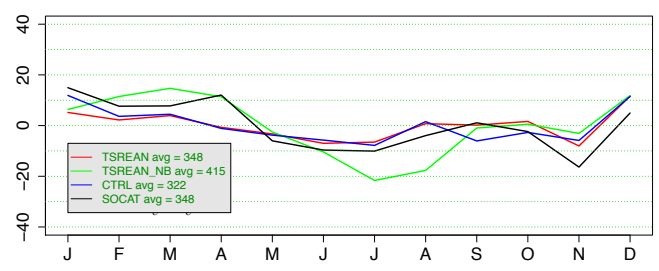

Fig. 9. Monthly climatological $\mathrm{pCO}_{2}$ for the years 2000-2010, averaged over different basins. Top: North (a) and South (b) Atlantic; Middle: North (c) and South (d) Pacific; Bottom: Indian (e). Each average is taken within the SOCAT grid points that contain actual data for each climatological map, see Fig. 8. For each figure, we have shown the anomaly for the SOCAT data (Black), the simulation (Blue), the reconstruction (Red), and the reconstruction without the effects of the biology included (Green). In each figure, the legend reports the average value of the $p \mathrm{CO}_{2}$ for that region.
BGD

11, 5399-5441, 2014

Impacts of physical

data assimilation on

the Global Ocean

Carbonate System

L. Visinelli et al.

\section{Title Page}

Abstract

Introduction

Conclusions

References

Tables

Figures

14

- I

4

Back

Close

\section{Full Screen / Esc}

Printer-friendly Version

Interactive Discussion 
(a)

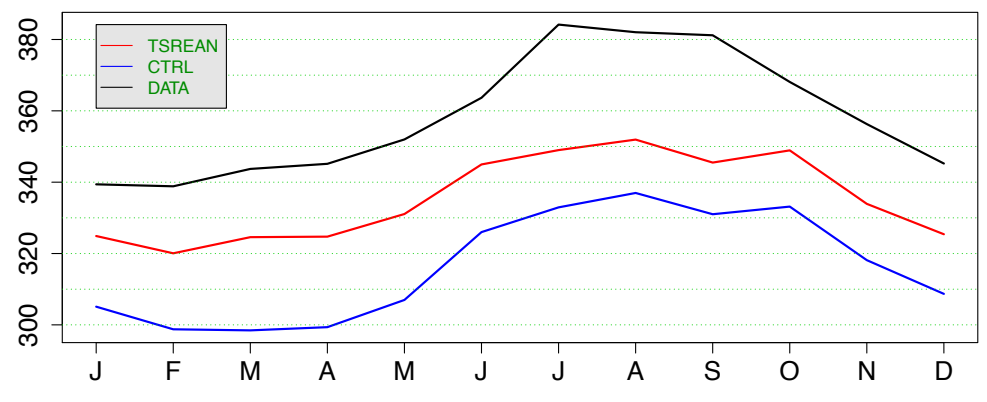

(b)

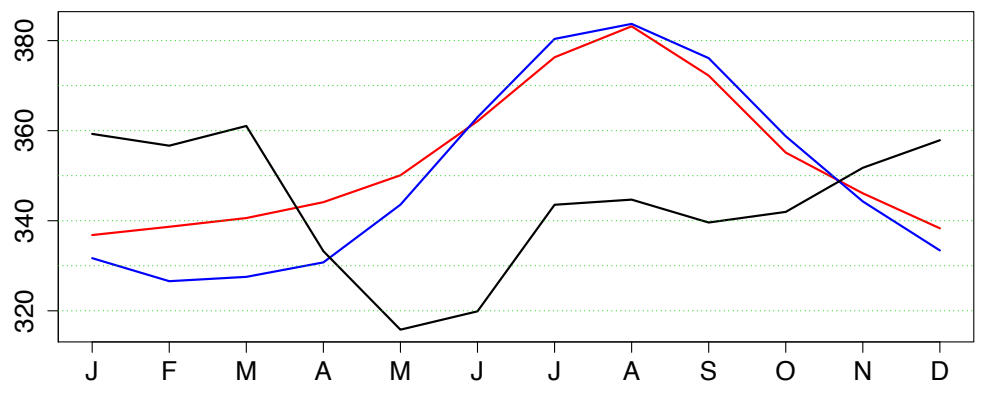

Fig. 10. Monthly climatological $p \mathrm{CO}_{2}$ averaged over the North Atlantic Ocean in the regions within $20^{\circ} \mathrm{N}$ and $40^{\circ} \mathrm{N}$ (a) and within $40^{\circ} \mathrm{N}$ and $70^{\circ} \mathrm{N}$ (b), for the SOCAT data (Black), CTRL (Blue), and TSREAN (Red). In each figure, the legend reports the average value of the $p \mathrm{CO}_{2}$ for that region.

\section{BGD}

$11,5399-5441,2014$

Impacts of physical

data assimilation on

the Global Ocean

Carbonate System

L. Visinelli et al.

\section{Title Page}

Abstract

Introduction

Conclusions

References

Tables

Figures

14

$\rightarrow 1$

4

Back

Close

Full Screen / Esc

Printer-friendly Version

Interactive Discussion 